\title{
Lake-floor sediment texture and composition of a hydrothermally-active, volcanic lake, Lake Rotomahana
}

\author{
A. Pittari *, S.L. Muir, C.H. Hendy \\ School of Science, The University of Waikato, Private Bag 3105, Hamilton, 3240, New Zealand
}

\section{A R T I C L E I N F O}

\section{Article history:}

Received 7 August 2015

Revised 22 February 2016

Accepted 25 February 2016

Available online xxxx

\section{Keywords:}

Lake Rotomahana

Lacustrine sediment

Volcanic lake

Hydrothermal system

Silica

\begin{abstract}
A B S T R A C T
Young volcanic lakes undergo a transition from rapid, post-eruptive accumulation of volcaniclastic sediment to slower pelagic settling under stable lake conditions, and may also be influenced by sublacustrine hydrothermal systems. Lake Rotomahana is a young (129 year-old), hydrothermally-active, volcanic lake formed after the 1886 Tarawera eruption, and provides a unique insight into the early evolution of volcanic lake systems. Lakebottom sediment cores, $20-46 \mathrm{~cm}$ in length, were taken along a transect across the lake and characterised with respect to stratigraphy, facies characteristics (i.e., grain size, componentry) and pore water silica concentrations. The sediments generally comprise two widespread facies: (i) a lower facies of light grey to grey, very fine lacustrine silt derived from the unconsolidated pyroclastic deposits that mantled the catchment area immediately after the eruption, which were rapidly reworked and redeposited into the lake basin; and (ii) an upper facies of dark, fine-sandy diatomaceous silt, that settled from the pelagic zone of the physically stable lake. Adjacent to sublacustrine hydrothermal vents, the upper dark facies is absent, and the upper part of the light grey to grey silt is replaced by a third localised facies comprised of hydrothermally altered pale yellow to yellowish brown, laminated silt with surface iron-rich encrustations. Microspheres, which are thought to be composed of amorphous silica, although some may be halloysite, have precipitated from pore water onto sediment grains, and are associated with a decrease in pore water silicon concentration. Lake Rotomahana is an example of a recently-stabilised volcanic lake, with respect to sedimentation, that shows signs of early sediment silicification in the presence of hydrothermal activity.
\end{abstract}

(c) 2016 Elsevier B.V. All rights reserved.

\section{Introduction}

Volcanic lakes undergo dynamic sedimentological changes in the few months to decades after their eruptive origin (e.g., Smith, 1991; Larson, 1993, and references therein). Re-established, or new hydrothermal systems are also a common feature of young volcanic lakes (e.g., Casadevall et al., 1984; Brantley et al., 1987; Christenson and Wood, 1993; Pasternak and Varekamp, 1997). Physical evidence for early sedimentation and environmental change within old volcanic lakes is often preserved in lake cores through volcaniclastic-lacustrine successions within maar-diatremes (e.g., Pirrung et al., 2003; Németh et al., 2008; Kaulfuss, 2013; Fox et al., 2015; Marchetto et al., 2015). Lake-bottom sediment core can also be used to infer the effects of volcanic tephra on the limnology of modern lakes (e.g., Rawlence, 1985; Fish, 1979). Lake Rotomahana, in the North Island of New Zealand, is an important example of a very young volcanic lake, in the classification of Christenson et al. (2015), which formed within a valley cut by a chain of craters, then dammed by volcanic material during and shortly after

\footnotetext{
* Corresponding author. Tel.: + 6478384191.

E-mail address: apittari@waikato.ac.nz (A. Pittari).
}

the June 10, 1886 Mount Tarawera eruption. Previous sediment cores from this lake (e.g., Trolle et al., 2008) have intersected both the modern pelagic lacustrine sediments and underlying volcaniclastic deposits associated with the 1886 eruption. This succession records significant process changes during the evolution of the lake. Active sublacustrine hydrothermal activity has also been detected on the lake floor (e.g., Walker et al., in this issue; de Ronde et al., in this issue). Thus, cores of lake sediment are likely to record near-surface physical evidence of this activity. This paper describes the physical characteristics of the sediments below the floor of Lake Rotomahana and discusses the post-eruptive sedimentological and hydrothermal processes associated with the young history of this volcanic lake.

\section{Geological and hydrothermal setting}

Lake Rotomahana is located within the southeastern margin of the Okataina Volcanic Complex, at the edge of the structural caldera boundary (Seebeck et al., 2010; de Ronde et al., in this issue). The country rock geology surrounding Lake Rotomahana was mapped and discussed by Nairn $(1989,2002)$ and Pittari et al. (in this issue), and comprises predominantly rhyolite lava domes and associated pyroclastic deposits, intra-caldera ignimbrites and outflow ignimbrites from other calderas. 
Localised basaltic scoria deposits have been documented on the northern and southern lake shores (Nairn, 1979, 1989, 2002), and associated basaltic dikes have been identified by a magnetic survey of the lake (Caratori Tontini et al., in this issue).

The modern geomorphology and hydrology of Lake Rotomahana (Figs. 1 and 2) are a consequence of landscape modifications from the June 10, 1886 Mount Tarawera eruption (e.g., Cole, 1970; Nairn, 1979; Keam, 1988, in this issue). The modern lake is $6.2 \mathrm{~km}$ long, oriented in a southwest to northeast direction, and is up to $2.5 \mathrm{~km}$ wide at its southwestern end, where it reaches a maximum depth of $130 \mathrm{~m}$. Fig. 1 shows the catchment streams for the lake, however there is no natural surface outlet; water seepage to Lake Tarawera occurs on the northern side. The Rotomahana lake level ( $337 \mathrm{~m}$ above sea level, a.s.l.) is $38 \mathrm{~m}$ higher than the level of Lake Tarawera ( $299 \mathrm{~m}$ a.s.l.). The lowest point on the rim between the two lakes is $343 \mathrm{~m}$ a.s.l. (Fig. 1) and an overflow pipe and culvert were constructed across this saddle in 1974 (R. Keam, personal communication). de Ronde et al. (in this issue) have identified fourteen phreatomagmatic maar and/or hydrothermal eruption craters on the lake floor, originating from the 1886 eruption. Prior to the eruption, the area was a swampy valley with two significantly smaller lakes, Lake Rotomahana and Lake Rotomakariri, to the northeast (Keam, in this issue). These lakes were drained to Lake Tarawera through the Kaiwaka Valley, which was subsequently filled by volcanic debris during the eruption creating a natural dam.
During the climactic phase of the Mount Tarawera eruption, which lasted for about $4 \mathrm{~h}$, a succession of craters was excavated along a $16 \mathrm{~km}$-long, northeast-trending linear structure across Mt. Tarawera, the lower-lying old lakes Rotomahana and Rotomakariri, and extending into the Waimangu Valley. Eruption vents across Mount Tarawera produced a basaltic plinian eruption column that dispersed a scoria fall deposit (Tarawera Pyroclastics Member, Nairn, 2002) largely to the northeast; scoria deposits surrounding Lake Rotomahana ranged from $3 \mathrm{~cm}$ (SE end) to $50 \mathrm{~cm}$ (NW end) (Walker et al., 1984). Eruption vents that formed along the extension of the linear structure to the southeast, across the low-lying lake region, produced a phreatomagmatic eruption column and pyroclastic base surges (Nairn, 1979), which were largely directed to the northwest. A lithic lapilli ash deposit, up to 20 m-thick (Rotomahana Pyroclastics Member, Nairn, 2002), mantled the landscape around the lake (Nairn, 1979; Pittari et al., in this issue).

Shortly after the eruption, the Rotomahana craters began to fill with cold water, which quenched much of the steam discharges associated with these by late 1887, and the lake had filled to its present level by the mid-1890s (Healy, 1975). Much of the post-eruptive sediment fill has accumulated in the largest craters of the central lake basin, up to $37 \mathrm{~m}$ in thickness (de Ronde et al., in this issue), and was probably transported here by lake bottom currents. Trolle et al. (2008) estimated a net sedimentation rate of $0.8 \mathrm{~mm} \mathrm{y}^{-1}\left(0.08 \mathrm{~kg} \mathrm{~m}^{-2} \mathrm{y}^{-1}\right)$ over the period 1886-2006, based on the depth to the Tarawera tephra in lake-

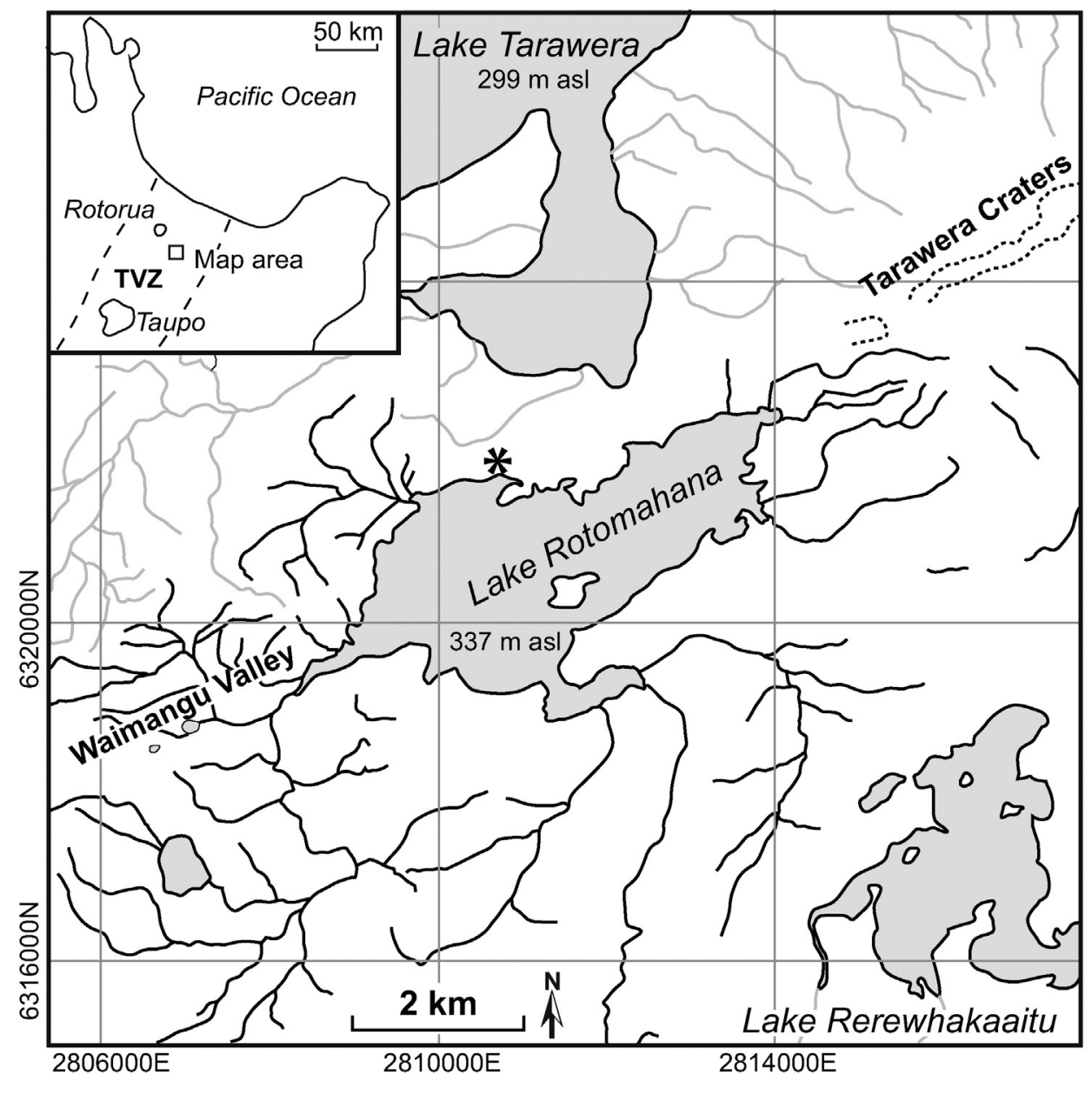

Drawn on the New Zealand Map Grid Projection

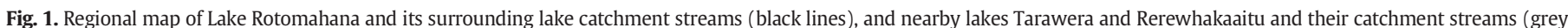

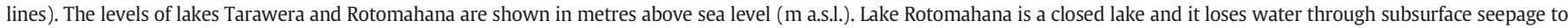

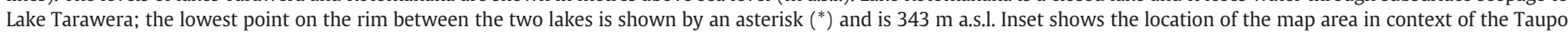
Volcanic Zone (TVZ). 


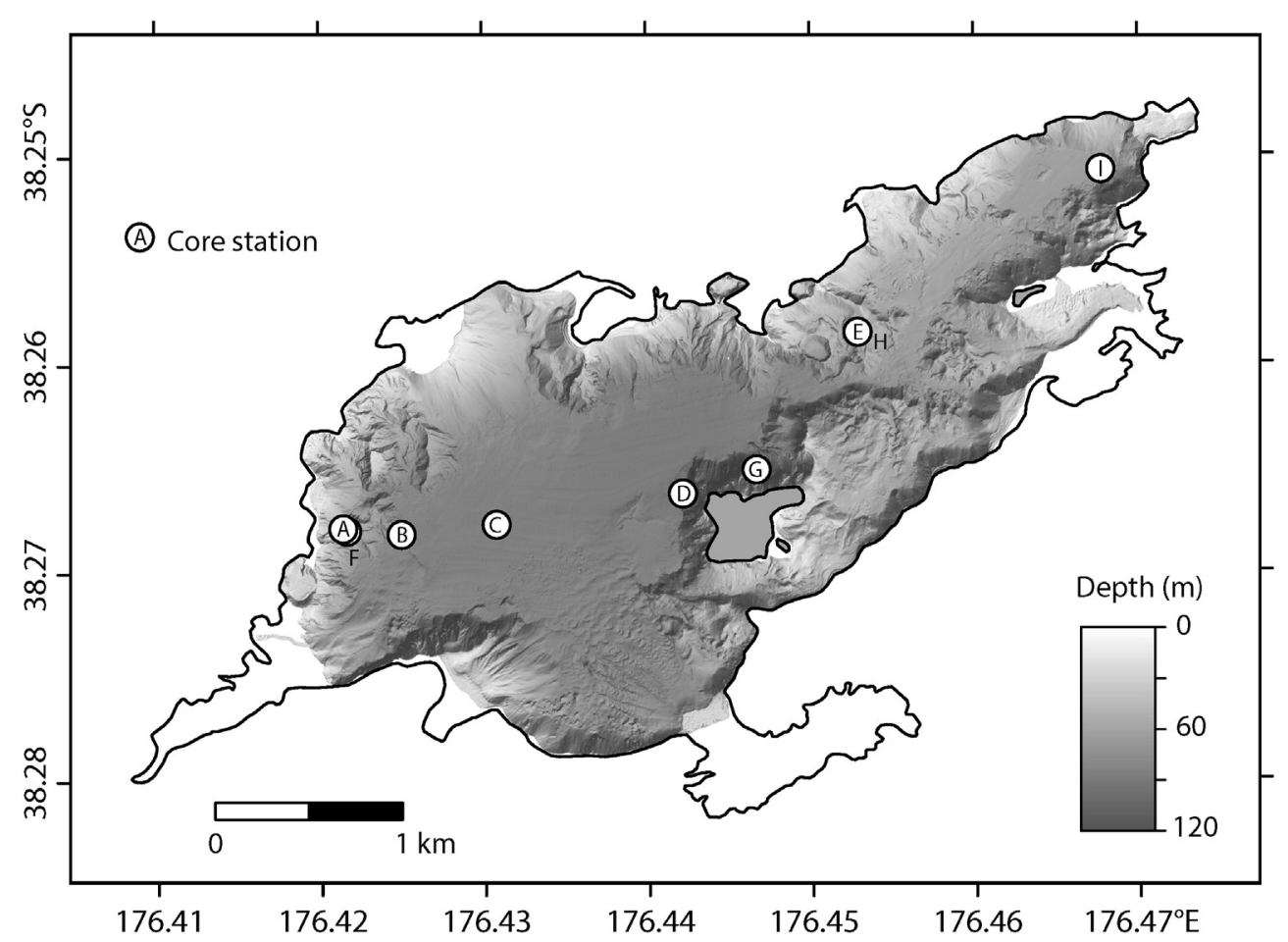

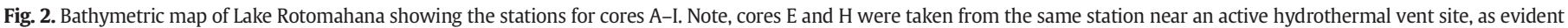
from continuous bubbling on the lake surface. Bathymetry after de Ronde et al. (in this issue).

bottom cores. However, this rate would have been much higher in the thicker section of the central lake basin.

The pre-eruptive hydrothermal landscape has been described by von Hochstetter and Petermann (1864) and von Hochstetter (1867). Prior to the 1886 eruption, surface hydrothermal activity was concentrated around the margins of the old Lake Rotomahana (Pink Terraces hydrothermal system) and included the famous Pink and White Terraces. After the eruption, much of the persistent steam had been inundated by rising lake levels, and by the 1890s a new area of surface hydrothermal activity had become established along eruption craters in the Waimangu Valley to the southwest (e.g., Simmons et al., 1993; Simmons and O'Sullivan, 2010; Hunt et al., 1994). Resistivity measurements (Bibby et al., 1994) and high heat flows in lake-bottom sediments (Whiteford and Graham, 1994; Tivey et al., in this issue) have suggested the presence of hydrothermal activity, especially in the western and southern parts of the lake. Recent multi-disciplinary geological, geophysical and geochemical surveys have identified that; (a) the old Pink Terraces hydrothermal system is still active on the northwestern side of the lake, and (b) a new system, the Patiti hydrothermal system, has been established on the southern part of the lake (de Ronde et al., in this issue), although both are likely to be connected at depth.

\section{Methods}

Nine lake sediment cores (A-I, Table 1), ranging from 20 to $46 \mathrm{~cm}$ in length, were obtained using a Pylonex HTH 70 mm sediment (gravity) corer from the bottom of Lake Rotomahana in water depths ranging from 49 to $112 \mathrm{~m}$ along a southwest-northeast profile (Fig. 2). Cores E and $\mathrm{H}$ were recovered near active hydrothermal vents in $49 \mathrm{~m}$ water depth, that were identified from bubbles at the lake surface. Upon recovery, cores A to $\mathrm{F}$ were photographed and sectioned into $1 \mathrm{~cm}$ segments and each scraped into Falcon ${ }^{\mathrm{TM}} 50 \mathrm{~mL}$ tubes. Cores $\mathrm{G}-\mathrm{I}$ were retained in their transparent tubes, and photographed and stratigraphically logged back in the laboratory.

The sectioned samples of cores A to F were initially weighed and then the pore water and sediment in each sample were separated in a centrifuge at $4000 \mathrm{rpm}$ for $30 \mathrm{~min}$. The pore fluid separated from the sectioned samples of cores A to F were filtered through a $0.45 \mu \mathrm{m}$

Table 1

Location, water depth, and total and individual facies thicknesses of lake bottom cores retrieved from Lake Rotomahana.

\begin{tabular}{|c|c|c|c|c|c|c|}
\hline \multirow[t]{2}{*}{ Core $\mathrm{e}^{\mathrm{a}, \mathrm{b}}$} & \multirow[t]{2}{*}{ Latitude, longitude } & \multirow[t]{2}{*}{ Water depth (m) } & \multirow[t]{2}{*}{ Core thickness $(\mathrm{cm})$} & \multicolumn{3}{|c|}{ Facies $(A-C)^{\mathrm{C}}$ thickness $(\mathrm{cm})$} \\
\hline & & & & A & B & $\mathrm{C}$ \\
\hline A & $38^{\circ} 16.080^{\prime} \mathrm{S}, 176^{\circ} 25.278^{\prime} \mathrm{E}$ & 53 & 37 & 20 & $>17$ & - \\
\hline B & $38^{\circ} 16.098^{\prime} \mathrm{S}, 176^{\circ} 25.492^{\prime} \mathrm{E}$ & 110 & 25 & $>25$ & - & - \\
\hline C & $38^{\circ} 16.070^{\prime} \mathrm{S}, 176^{\circ} 25.842^{\prime} \mathrm{E}$ & 112 & 25 & $>25$ & - & - \\
\hline $\mathrm{D}$ & $38^{\circ} 15.982^{\prime} \mathrm{S}, 176^{\circ} 26.528^{\prime} \mathrm{E}$ & 92 & 27 & $>27$ & - & - \\
\hline $\mathrm{E}$ & $38^{\circ} 15.515^{\prime} \mathrm{S}, 176^{\circ} 27.173^{\prime} \mathrm{E}$ & 49 & 35 & - & $>30$ & 4.5 \\
\hline $\mathrm{F}$ & $38^{\circ} 16.088^{\prime} \mathrm{S}, 176^{\circ} 25.280^{\prime} \mathrm{E}$ & 55 & 33 & 16 & $>17$ & - \\
\hline G & $38^{\circ} 15.912^{\prime} \mathrm{S}, 176^{\circ} 26.786^{\prime} \mathrm{E}$ & 70 & 46 & 21 & $>25$ & - \\
\hline $\mathrm{H}$ & $38^{\circ} 15.515^{\prime} \mathrm{S}, 176^{\circ} 27.173^{\prime} \mathrm{E}$ & 49 & 25 & - & $>18$ & 6 \\
\hline I & $38^{\circ} 15.046^{\prime} \mathrm{S}, 176^{\circ} 28.069^{\prime} \mathrm{E}$ & 71 & 20 & 20 & - & - \\
\hline
\end{tabular}

a Cores $\mathrm{E}$ and $\mathrm{H}$ were obtained from the same location, near an active hydrothermal vent.

b Cores A-F were split into $1 \mathrm{~cm}$ intervals (upper 15-20 cm only for A, E and F; whole core for B-D) in the field for grainsize (E and F only), pore fluid chemistry, loss on ignition and density analyses. Cores $\mathrm{G}-\mathrm{I}$ were retained and logged in the laboratory; $\mathrm{G}$ and $\mathrm{H}$ were sub-cored for SEM analysis.

c See text for definition of facies A-C. 


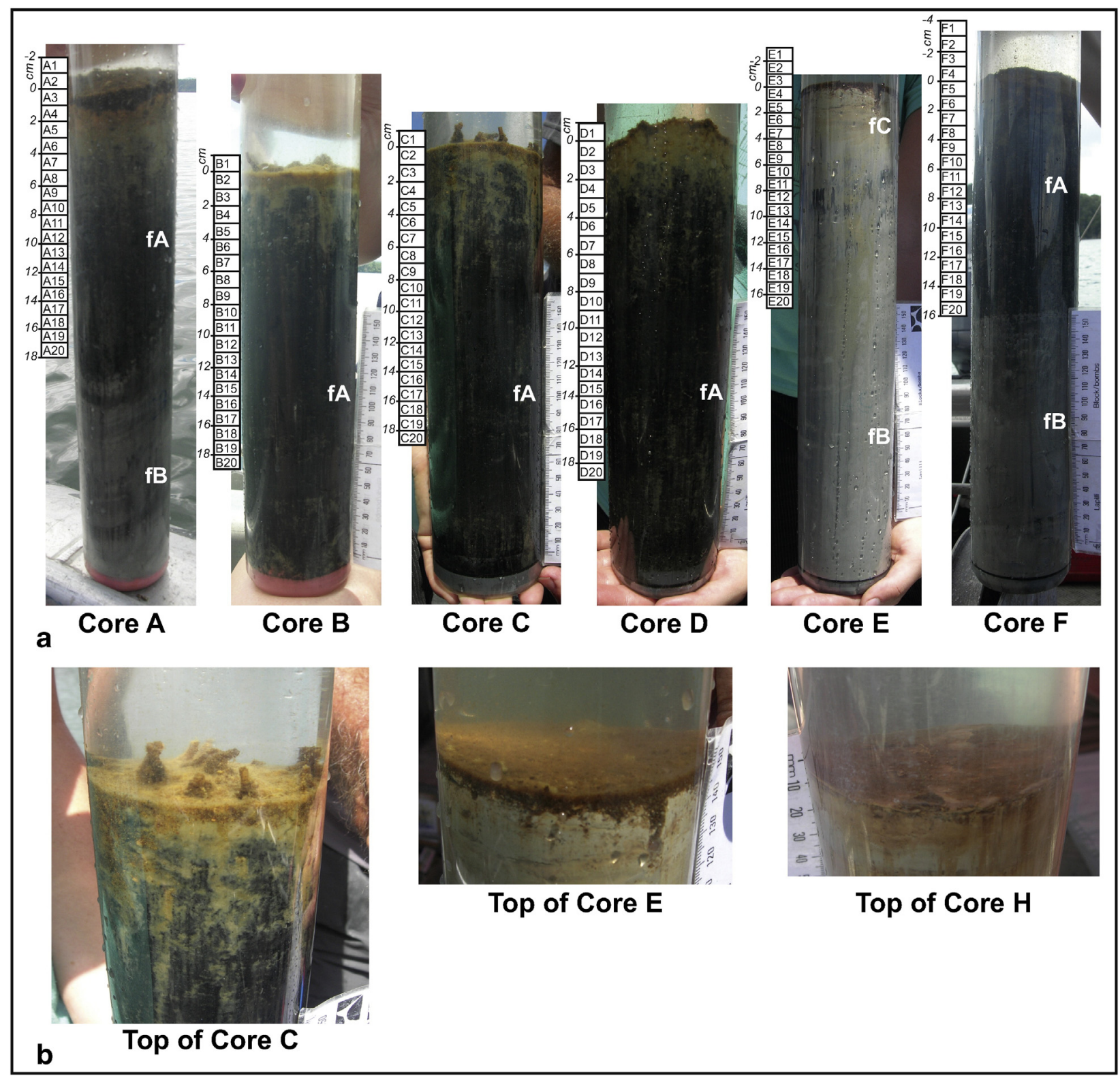

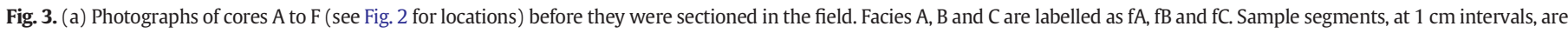

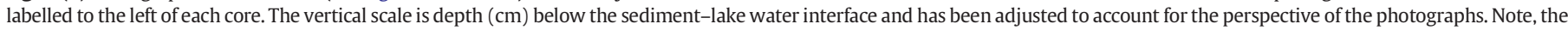

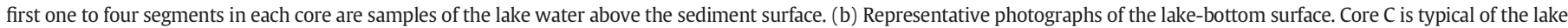
bottom, whereas cores $\mathrm{E}$ and $\mathrm{H}$ were sampled near a hydrothermal vent. Core $\mathrm{H}$ is shown in Fig. 3. Core tube width is $70 \mathrm{~mm}$.

millipore filter and then $5 \mathrm{~mL}$ subsamples were acidified with concentrated nitric acid $(0.1 \mathrm{~mL})$. Elemental concentrations were measured by inductively coupled plasma mass spectrometry (ICP-MS model ELAN DRC II; Perkin-Elmer SCIEX). Only silicon and aluminium concentrations are reported here, as they are of relevance to understanding the origin of microspheres identified in Section 6.

The sediments were dried, weighed and ground with a mortar and pestle to disaggregate lumps. Loss on ignition was measured by heating $0.2 \mathrm{~g}$ samples of dry sediment in a muffler furnace at $450{ }^{\circ} \mathrm{C}$ for 3.5 to $4 \mathrm{~h}$ and calculating the weight lost.

Subsamples of the dried, ground sediment separates from the sectioned samples of cores $\mathrm{E}$ and $\mathrm{F}$ were treated with $10 \% \mathrm{H}_{2} \mathrm{O}_{2}$ to remove organic matter. Later, grain size analyses were conducted using a Malvern Mastersizer 2000 laser diffraction particle size analyser.

Sub-cores $10 \mathrm{~mm}$ in diameter of cores $\mathrm{G}$ and $\mathrm{H}$ were extracted using a glass tube. Four samples from the sub-core of core $G$, and three from core $\mathrm{H}$, were dried, mounted on stubs and coated with platinum for examination using a HITACHI S-4700 field emission scanning electron microscope (SEM). SEM images were obtained using an accelerating voltage of 3 or $5 \mathrm{kV}$. At a later date, a further three samples from core G (G5 to G7) were prepared in the same way with semi-quantitative elemental compositions of selected components analysed using a ThermoNoran System 6 energy dispersive spectroscopic (EDS) system attached to the SEM, using an accelerating voltage of $20 \mathrm{kV}$.

Two additional samples from core H (sample G8) and two samples from core $\mathrm{H}$ ( $\mathrm{H} 4$ and $\mathrm{H} 5$ ) were prepared for clay mineral identification, with special emphasis on halloysite, by X-ray diffractometry (XRD) following the method of Cunningham (2012). The clay fraction was separated by centrifuge and treated with $\mathrm{MgCl}_{2}$, then pipetted onto a ceramic tile and air-dried over distilled water for $24-72 \mathrm{~h}$ to prevent irreversible halloysite dehydration (Kirkman and Pullar, 1978). The clay samples were initially scanned by a Panalytical Empyrean X-ray diffractometer from $2^{\circ}$ to $45^{\circ} 2 \theta$, at 120 s per step using a copper K-alpha 


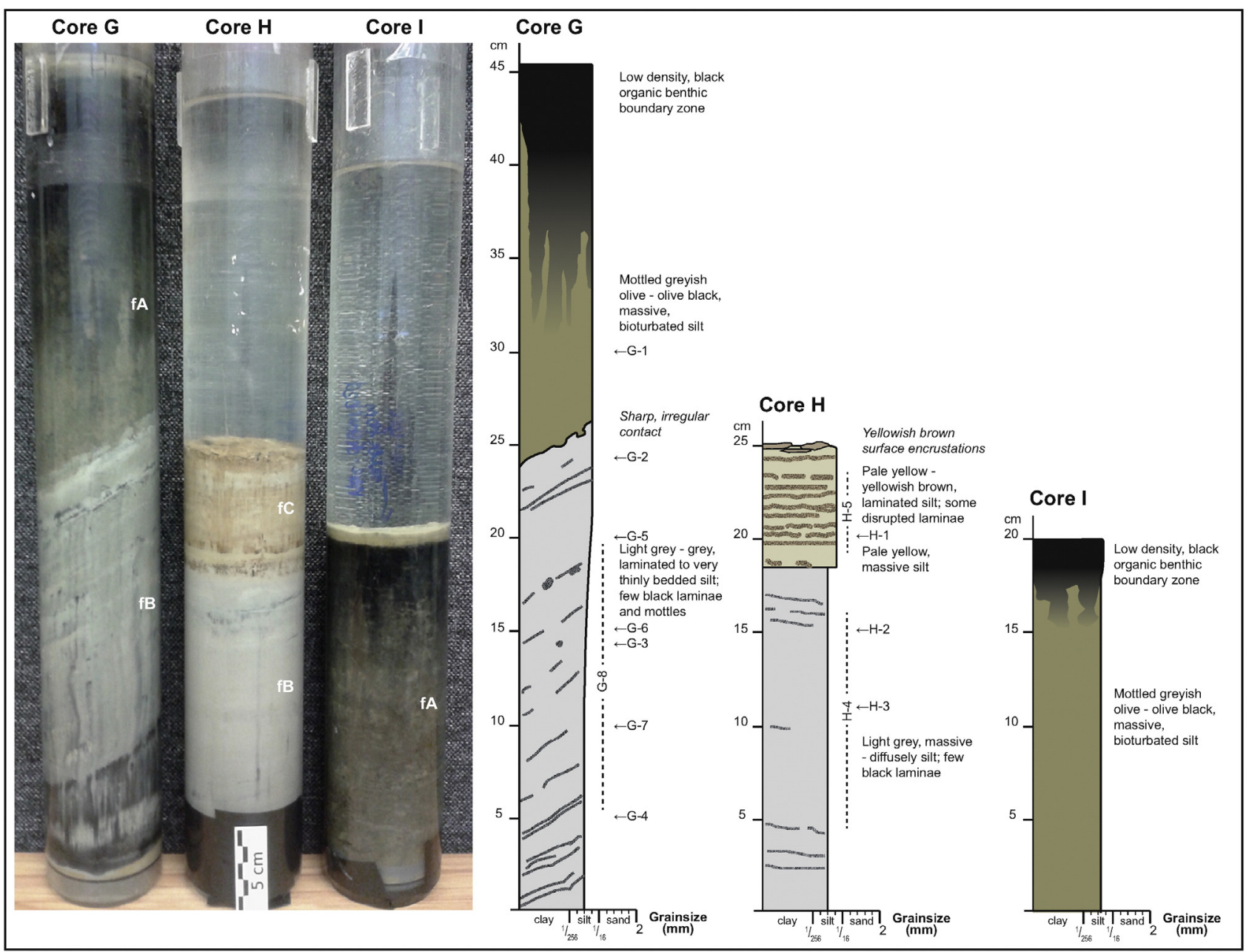

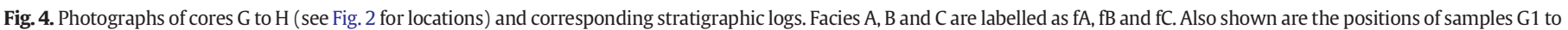
G8 and $\mathrm{H} 1$ to H5 taken from sub-cores and used for SEM analysis. Note samples G8, H4 and H5 were taken from the thickness range shown.

source. Further scans were repeated after heating the samples to $110^{\circ} \mathrm{C}$, and then to $550{ }^{\circ} \mathrm{C}$.

\section{Facies characteristics and stratigraphy}

Photographs of cores A to I are shown in Figs. 3 and 4, with stratigraphic logs for cores $G$ to I also shown in Fig. 4. Three distinctive depositional facies (A, B and C, Table 1) occur in the lake bottom sediments of Lake Rotomahana, and are distinguished by their visible colour and depositional structure. All facies have a silty texture and grain size characteristics have been determined for cores $\mathrm{E}$ and $\mathrm{F}$ (Fig. 5).

Facies A, which forms the uppermost layer in most cores across the lake (although it is absent in cores $\mathrm{E}$ and $\mathrm{H}$ ), is a mottled greyish-olive to olive black, massive, bioturbated, organic-rich silt (Figs. 3a, 4). It is between 16 to $21 \mathrm{~cm}$-thick in water depths between 53 and $71 \mathrm{~m}$, and is the only facies observed in cores at greater water depths (i.e., 71$112 \mathrm{~m}$ ) (Table 1) where it has an increased thickness ( $>25 \mathrm{~cm}$ or $>27 \mathrm{~cm}$ ) beyond the limit of core penetration. Grain size data for this facies is from core $\mathrm{F}$ (from $55 \mathrm{~m}$ water depth; samples F6-F20, Fig. 5) and typically shows a poorly sorted, fine sandy medium silt throughout the facies thickness, with 29-35 vol.\% sand in the upper $4 \mathrm{~cm}$, grading down to $16-22$ vol.\% sand in the lower $9 \mathrm{~cm}$. Clay content is low (2-9 vol.\%). The grain size distribution is typically bimodal with a major peak at fine to medium silt and a smaller peak at fine sand, the latter of which becomes lower with depth. The uppermost $1-2 \mathrm{~cm}$ is a distinctive pale yellow to yellowish brown oxidised horizon. This horizon overlies an anoxic zone of black, organic-rich ooze, which then grades down to the typical mottled zone of facies A. Benthic macroinvertebrate fauna, especially bloodworms (chironomid larvae), have burrowed extensively through the oxidised and anoxic zones down to a maximum of $10 \mathrm{~cm}$ (Fig. 3b, core C). The top surface of this facies is often characterised by vertical, sediment-coated tube structures that are associated with these burrows. (Fig. 3b, Core C).

Facies B is a light grey to grey, laminated to very thinly bedded or massive silt, with few black laminae or mottles (Figs. 4a, 5). It occurs directly beneath, and typically in sharp contact with, facies A or C (see below) in cores where it was intersected (i.e., water depths between 49 and $71 \mathrm{~m}$ ). Intervals of this facies, ranging from 17 to $30 \mathrm{~cm}$-thick, were recovered, but the base was not intersected (Table 1). Grain size data for this facies is from core $\mathrm{E}$ (from $49 \mathrm{~m}$ water depth; samples E9-E20, Fig. 5) and typically shows unimodal, very fine silt, with significantly lower sand (2-6 vol.\%) and higher clay (22-36 vol.\%) contents relative to facies $A$.

Facies $C$ is a pale yellow to yellowish brown, laminated silt, with some disrupted laminae (Figs. 3a, 4). It occurs as the uppermost layer, 4.5 to $6 \mathrm{~cm}$-thick in cores proximal to hydrothermal vents (cores $\mathrm{E}$ and $\mathrm{H}$; water depth, $49 \mathrm{~m}$; Table 1), and sharply overlies facies B. The top surface of this facies in core $\mathrm{H}$ has yellowish brown encrustations (Fig. 3) and in core E an $\sim 1 \mathrm{~cm}$ layer of yellowish brown flocculent sediment (Fig. 3), and is devoid of visible macroscopic benthic organisms (Fig. 3b). Grain size data for this facies is from the upper $5 \mathrm{~cm}$ of core E (samples E4-E8, Fig. 5) and typically shows poorly sorted, clayey very fine silt, with low sand (1-5 vol.\% and high clay (19-23 vol.\%) contents comparable to facies $\mathrm{B}$. The grain size distribution is slightly 


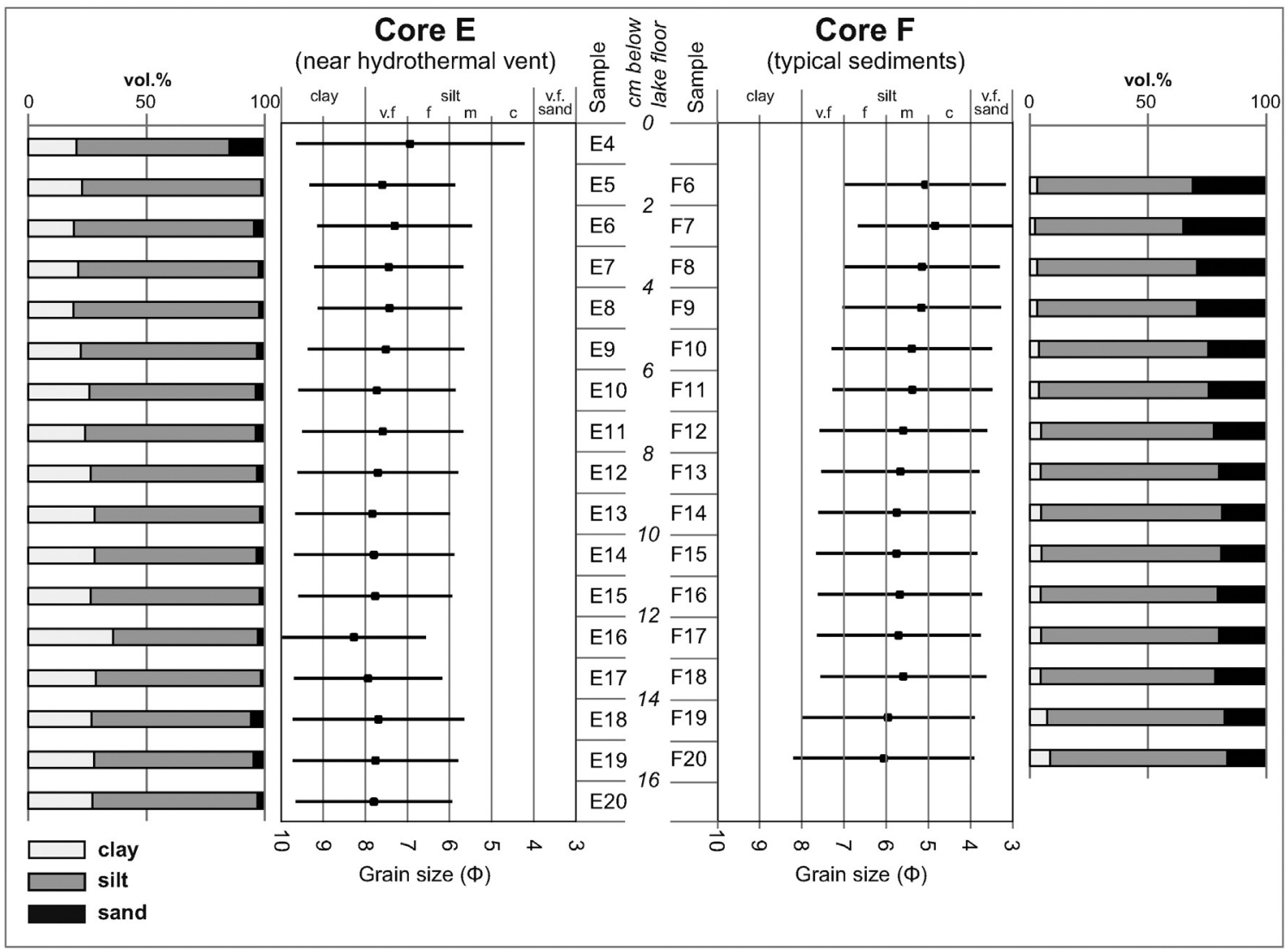

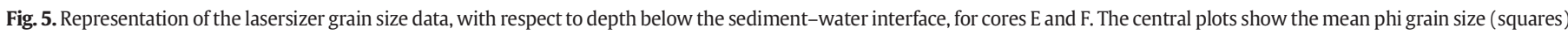

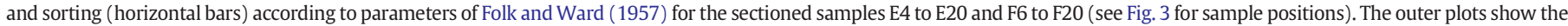
volume percentage proportions of sand, silt and clay in each sample. See Fig. 2 for sample locations. v.f. $=$ very fine, $f=$ fine, $m=$ medium, $c=$ coarse.

bimodal with peaks in the clay and fine to medium silt fractions. Higher sand content in the upper $1 \mathrm{~cm}(15 \mathrm{vol} . \%)$, coincides with the yellowish brown flocculent bed.

In several cores recovered from water depths between 53 and $70 \mathrm{~m}$ (e.g., cores $\mathrm{A}$ and $\mathrm{G}$ ), laminae dip at an angle of around $30^{\circ}$.

\section{Sediment organic content}

Loss on ignition (LOI), which is a proxy for assessing the organic content in sediment, is plotted as a function of depth in Fig. 6. Cores A to D and $\mathrm{F}$, which were sampled mainly through facies A, generally show relatively high LOI values at the top of each core (10-16 wt.\%), but decrease with depth down to 5-8 wt.\%. Cores A, C, D and F show a sharp decrease in LOI below the 13-15 cm interval Core E, which was sampled near a hydrothermal vent, through facies B and C, has a significantly lower LOI value (2-3 wt.\%) and does not show a changing trend with depth.

\section{Physical composition of the sediment}

The physical composition of the sediment has been documented from observations using the SEM. Representative images from successive deeper samples below the lake floor for cores $\mathrm{G}$ and $\mathrm{H}$ are shown in Figs. 7 and 8, respectively. Six different component types have been documented here: diatoms, flaky particles, granular particles, glass shards, microspheres and tubular clays.

Diatom frustules range from fine silt- to fine sand-sized (long axis) particles. Intact diatom frustules occur as long, rectangular or boatshaped, pennate forms and as disc-shaped, and centric forms (Fig. 7a and $\mathrm{b}$ ). The pennate diatom frustules are typically $100-200 \mu \mathrm{m}$-long and 5-10 $\mu \mathrm{m}$-wide and have tapered ends. Centric diatoms are typically

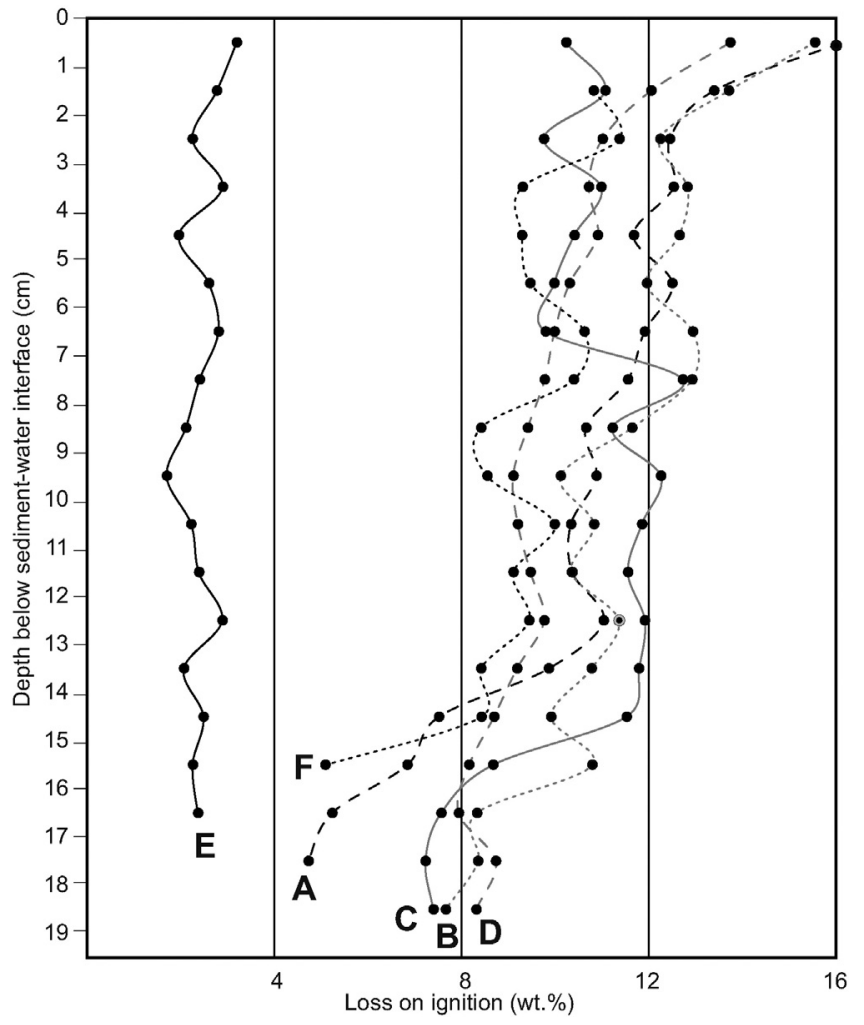

Fig. 6. Loss on ignition (LOI, wt.\%) plotted as a function of sample depth below the sedimentwater interface for cores A to F (labelled). LOI is a proxy for sediment organic content. See Figs. 2 and 3 for sample locations and their stratigraphic positions, respectively. 


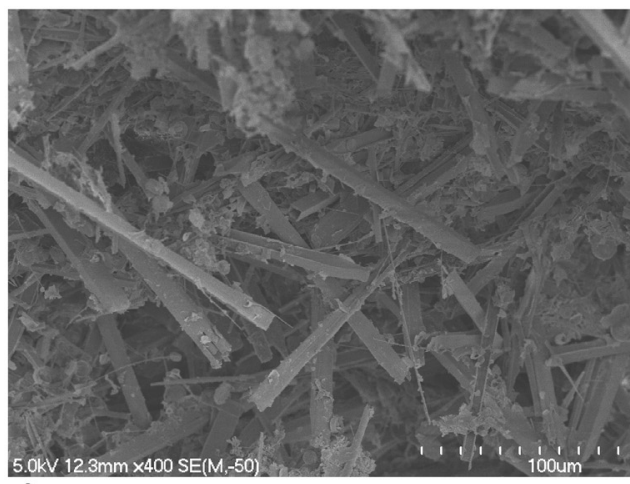

a) Sample G1, Facies A, $16 \mathrm{~cm}$

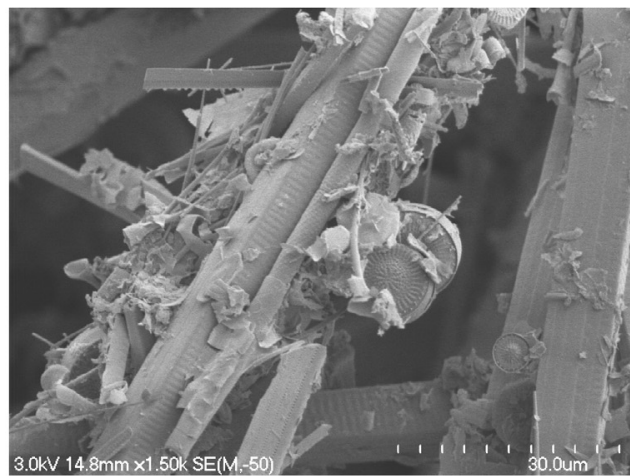

b) Sample G1, Facies A, $16 \mathrm{~cm}$

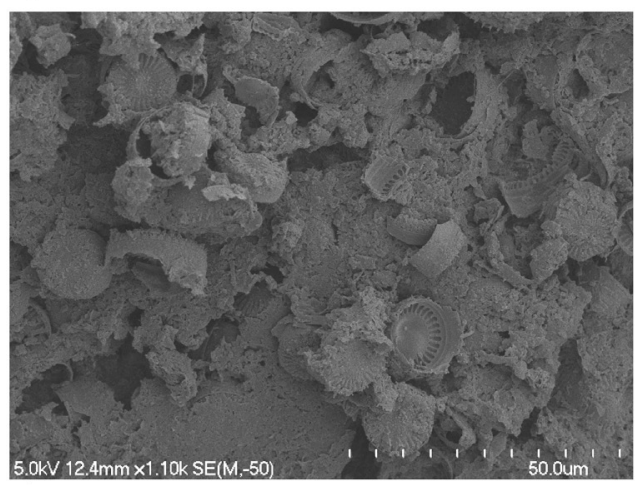

C) Sample G2, Facies B, $22 \mathrm{~cm}$

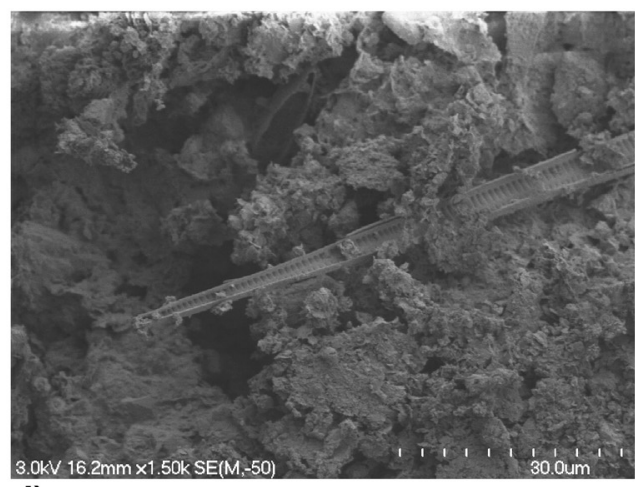

d) Sample G3, Facies B, $32 \mathrm{~cm}$

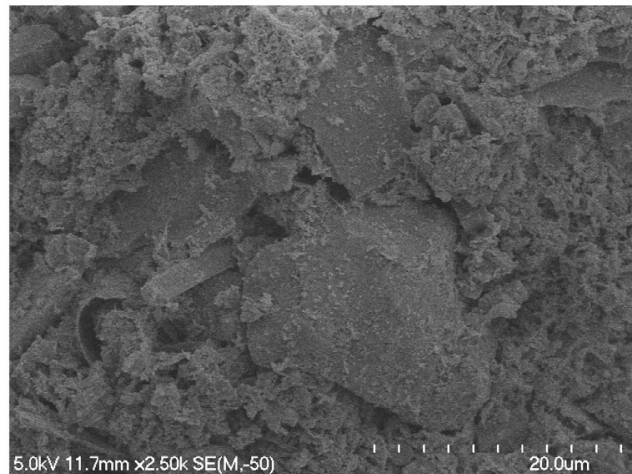

e) Sample G3, Facies B, $32 \mathrm{~cm}$

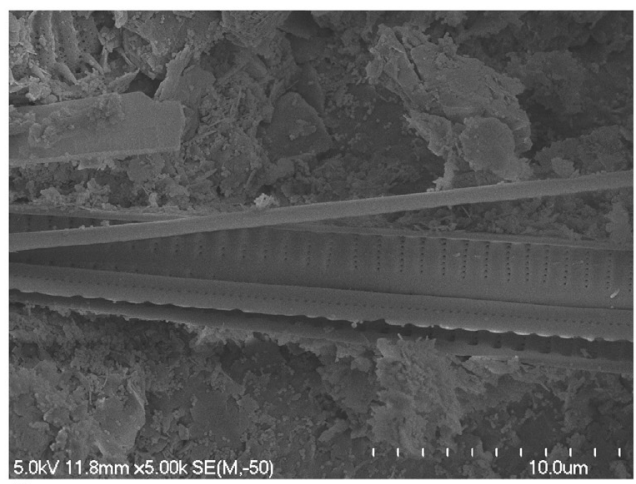

f) Sample G4, Facies B, $41 \mathrm{~cm}$

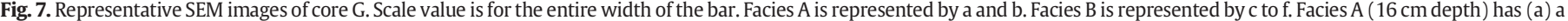

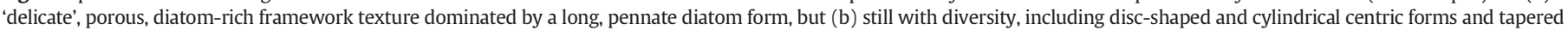

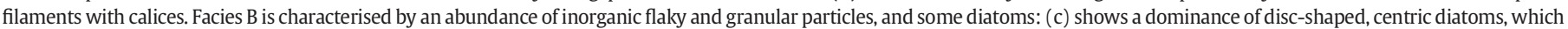

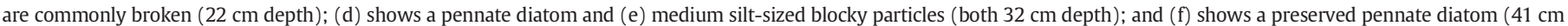
depth). See Figs. 2 and 4 for sample locations and their stratigraphic positions, respectively.

10-20 $\mu \mathrm{m}$ in diameter and $10 \mu \mathrm{m}$-thick. There are also long, thin, segmented, and cylindrical species, typically $3 \mu \mathrm{m}$ in diameter and greater than $100 \mu \mathrm{m}$-long (Fig. 7b). Broken fragments of diatom frustules commonly occur as irregularly-shaped flakes with regular areolae (pore) patterns. Thin $(<1 \mu \mathrm{m}$-diameter) tapered filaments, typically up to $30 \mu \mathrm{m}$-long, sometimes with a calyx (cup) at one end, also occur in the diatomaceous sediment (Fig. 7b).

Inorganic grains generally range from clay to medium silt in size and include flaky particles, granular particles, glass shards, microspheres and tubular clays. Thin (sub-micron-thick) flaky particles are typically 2-5 $\mu \mathrm{m}$-wide, with angular edges, and are often corrugated, or folded (Fig. 8a-c). They are distinct from broken diatom flakes in that they lack pores. Granular particles, which are predominantly mineral grains or occasional rock fragments, are characterised by blocky shapes, typically 1 to $25 \mu \mathrm{m}$ in diameter (Figs. 7d and e; $8 \mathrm{~d}$ and e); some blocky particles may be basalt fragments derived from the magma of the 1886
Tarawera eruption (c.f. Nairn, 1979). Particles that can be positively identified as glass shards are present, but not common (Fig. 8d).

Also present in some samples are sub-micron-sized microspheres, ranging from 120 to $250 \mathrm{~nm}$ in diameter that occur on the surfaces of larger grains (Fig. 9a), in pore spaces (Fig. 9b) and as dense aggregates (Fig. 9c). Spot EDS analyses on selected aggregates of microspheres, as well as several other particles for comparison, are presented in Table 2. However, due to the small size of the microspheres and wider EDS beam, there is some cross-contamination with the included analyses of adjacent grains and thus the data need to be treated with caution. The silicon-aluminium atomic ratio for the microspheres varies from 5.9 to 13.9 and is presented as a proxy for assessing whether these are siliceous microspheres, or a spheroidal clay mineral, such as halloysite (see Section 8.3).

Localised aggregates of tubular clays, typically $100 \mathrm{~nm}$ in diameter and 400-800 nm-long, occur in facies C (sample H1, Fig. 8b). 

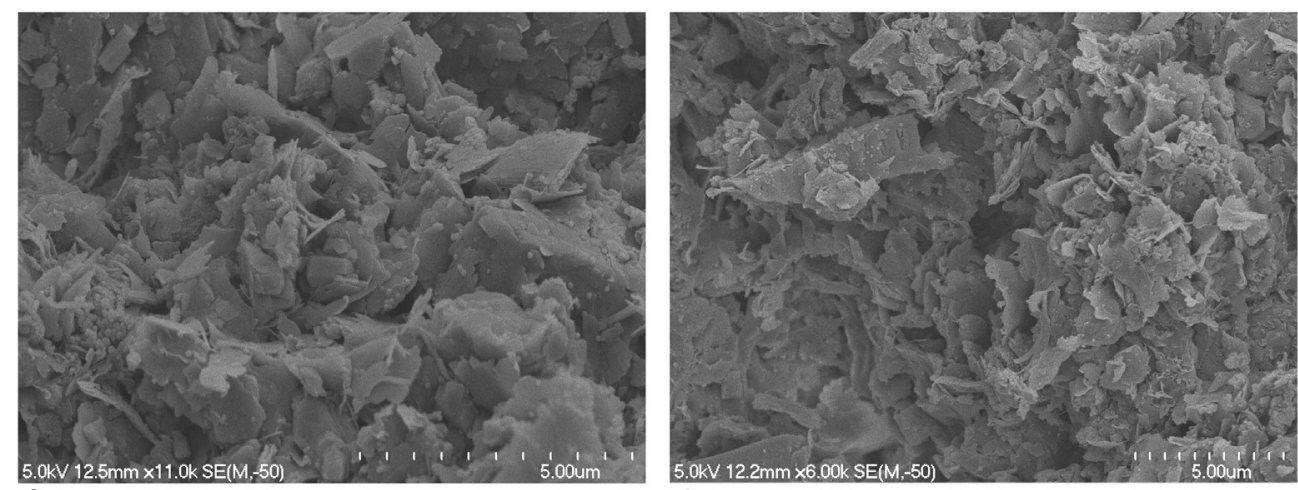

a) Sample $\mathrm{H} 1$, Facies $\mathrm{C}, 5 \mathrm{~cm}$

c) Sample H2, Facies B, $11 \mathrm{~cm}$
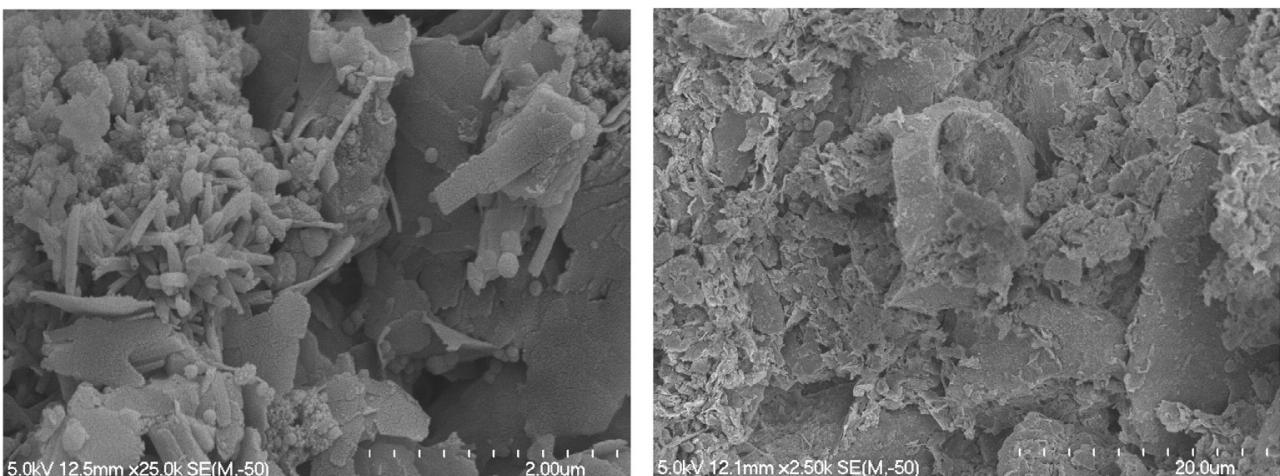

b) Sample H1, Facies C, $5 \mathrm{~cm}$

d) Sample H2, Facies B, $11 \mathrm{~cm}$

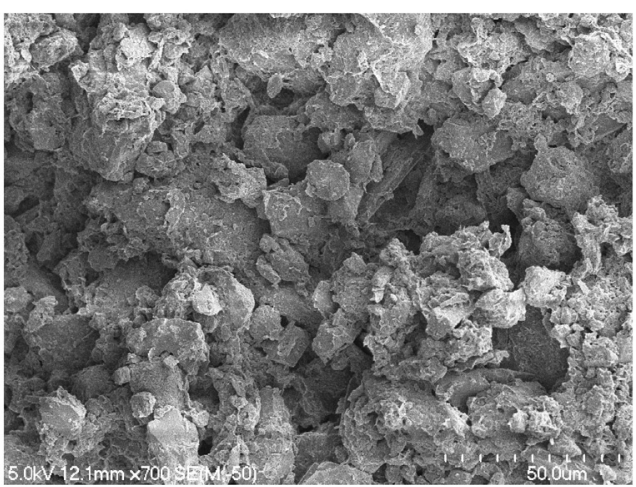

e) Sample H3, Facies B, $14 \mathrm{~cm}$

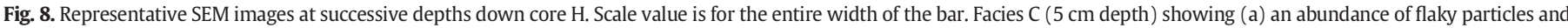

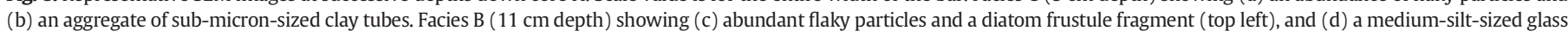

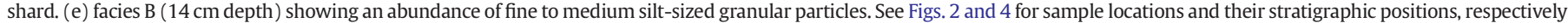

Overall, facies A is characterised by having a diversity of pennate and centric diatoms, with the pennate forms larger and more abundant. This contrasts with the underlying facies B, which predominantly has flaky and granular particles. Less abundant diatoms in facies B, have a lower diversity and the centric species are dominant over pennate species. Glass shards have only been observed in facies $\mathrm{B}$. The physical composition of facies $\mathrm{C}$ is similar to facies $\mathrm{B}$, but aggregates of tubular clays are also present in facies $\mathrm{C}$. Microspheres were found in facies B and C; they occur at a depth of $\sim 25$ to $32 \mathrm{~cm}$ in core G (i.e. samples G3-G7), and near-surface between 0 to $5 \mathrm{~cm}$ in core $\mathrm{H}$ (i.e., samples $\mathrm{H} 1-\mathrm{H} 3$ ).

XRD traces on clay separates from facies B (sample G8 and H4) and facies C (sample H5) are presented in Fig. 10. Reference tables from Whitton and Churchman (1987) and Lowe and Nelson (1983) were used to identify clay minerals. A distinctive peak at d-spacings of $18.63 \AA$ (sample G8) or $18.90 \AA$ (sample H4) that decreases to background levels on heating to $110{ }^{\circ} \mathrm{C}$ represents a form of hydrated montmorillonoid. A peak at $14.15 \AA$ (sample H4), which decreases and shifts to $13.56 \AA$ upon heating to $550{ }^{\circ} \mathrm{C}$, is consistent with an interlayered hydrous mica (i.e., vermiculite with aluminium hydroxyl interlayers). Primary peaks for quartz (3.33-3.34 A) and feldspar (3.19-3.20 ̊) occur for all samples.

In all samples there are two related peaks at $\sim 10 \AA$ (9.76 $\AA$, sample G8; $9.98 \AA$ A, sample H4; $9.76 \AA$, sample H5) and $7 \AA$ (6.99 A, sample G8; $7.05 \AA$, sample $H 4 ; 6.99 \AA$, sample H5). In all samples the $\sim 10 \AA$ peak is preserved upon heating to $110^{\circ} \mathrm{C}$ and $550{ }^{\circ} \mathrm{C}$, which is consistent with illite, although there may be a small contribution from dehydrated montmorillonoids or vermiculite at $550{ }^{\circ} \mathrm{C}$. The $\sim 7 \AA$ peak, in all samples, decreases to background levels upon heating to $550{ }^{\circ} \mathrm{C}$ which indicates either kaolinite or dehydrated halloysite. The peak at $\sim 3.5 \AA$ (3.52 $\AA$, sample G8; $3.53 \AA$, sample H4; $3.51 \AA$, sample H5) is a second order peak for kaolinite or dehydrated halloysite. In sample G8, the $\sim 10$ A peak decreases significantly relative to the $\sim 7 \AA$ peak upon heating to $110{ }^{\circ} \mathrm{C}$, which suggests the presence of halloysite (i.e., hydrated 10 Å halloysite converts to dehydrated $7 \AA$ Å halloysite during the lower heating step, $110^{\circ} \mathrm{C}$, before all halloysite disintegrates at 


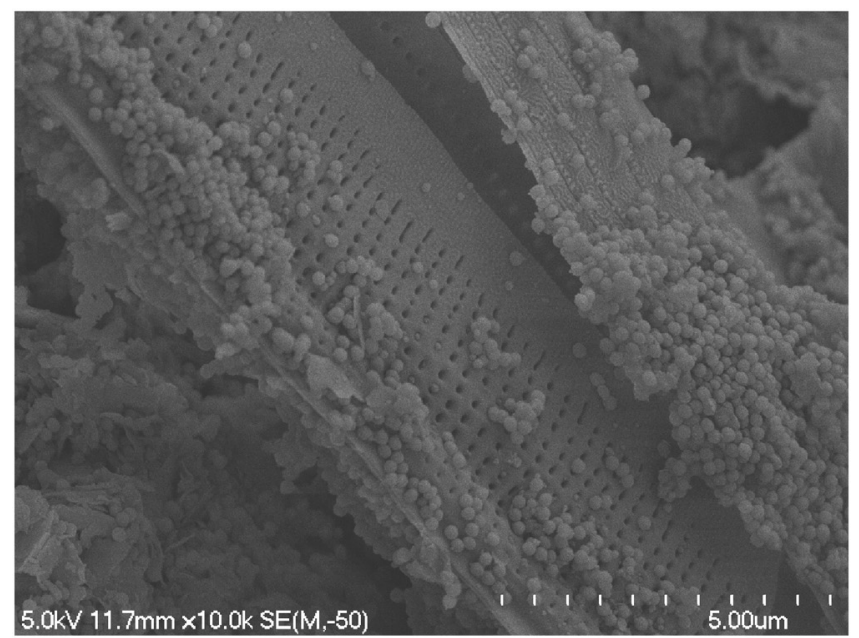

a) Sample G3, $32 \mathrm{~cm}$

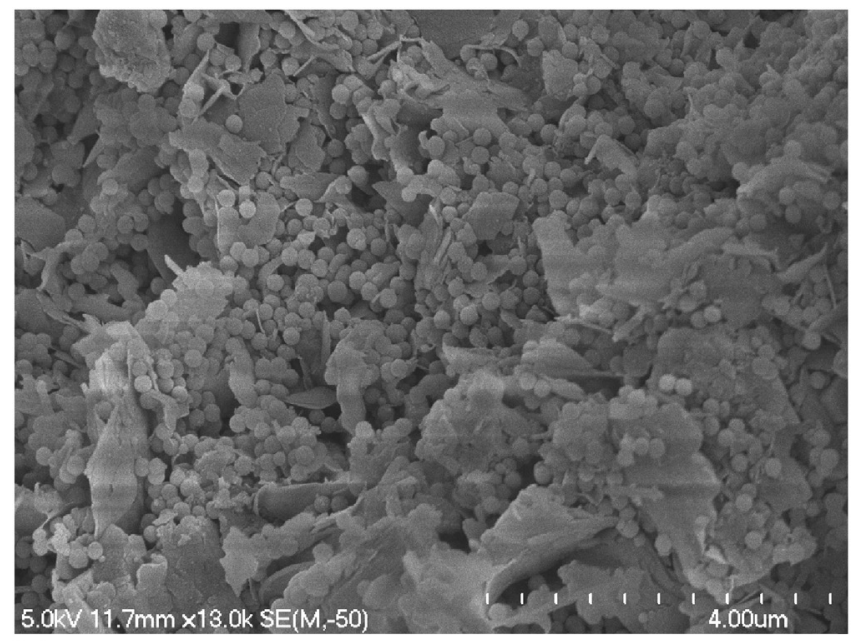

b) Sample G3, $32 \mathrm{~cm}$

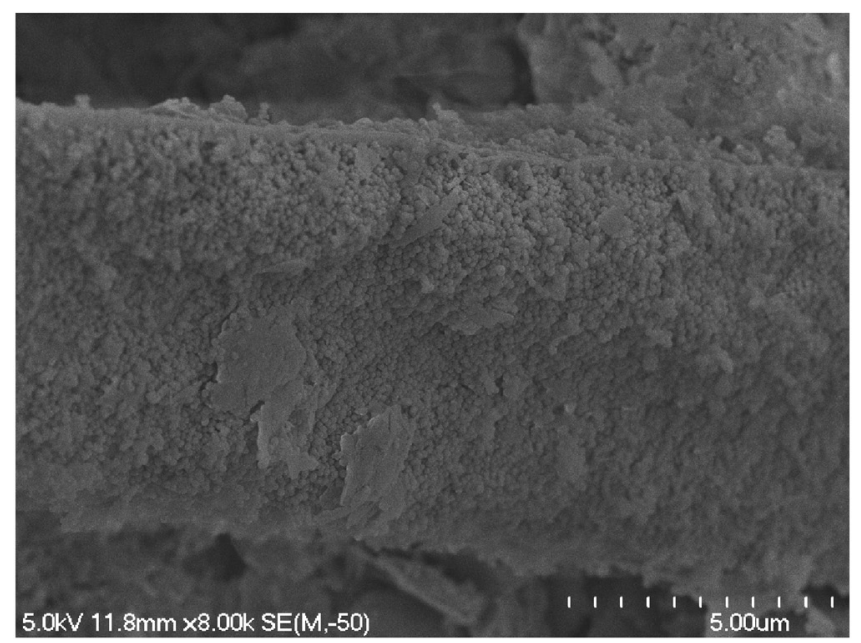

\section{c) Sample G4, $41 \mathrm{~cm}$}

Fig. 9. Representative SEM images from core G showing microspheres (a) coating the surface of a diatom frustule (depth, $32 \mathrm{~cm}$ ), (b) filling pore space between flaky particles, and (c) as a dense aggregate. Scale value is for the entire width of the bar. See Figs. 2 and 4 for sample locations and their stratigraphic positions, respectively.

$\left.550{ }^{\circ} \mathrm{C}\right)$. Hydrated 10 Å halloysite was not identified in samples $\mathrm{H} 4$ and $\mathrm{H} 5$, hence the presence of dehydrated $7 \AA$ halloysite over kaolinite in these samples remains inconclusive.
Table 2

Semi-quantitative EDS analyses of aggregates of microspheres, and other constituents in facies B from core $G$

\begin{tabular}{llllllr}
\hline Sample $^{\mathrm{a}}$ & Constituent & $\begin{array}{l}\text { Atom\% } \\
\mathrm{Si}\end{array}$ & $\begin{array}{l}\text { Atom\% } \\
\mathrm{Al}\end{array}$ & $\begin{array}{l}\text { Atom\% } \\
\text { Fe }\end{array}$ & $\begin{array}{l}\text { Atom\% } \\
\text { K }\end{array}$ & $\begin{array}{l}\text { Si: Al } \\
\text { value }\end{array}$ \\
\hline G-5 & Microsphere aggregate & 54.28 & 8.09 & 8.96 & 4.85 & 6.71 \\
G-5 & Microsphere aggregate & 35.09 & 4.86 & 2.50 & 1.43 & 7.22 \\
& & 41.1 & 5.78 & 3.15 & 2.54 & 7.11 \\
& & 37.85 & 6.42 & 3.38 & 2.75 & 5.90 \\
G-5 & Granular particle & 26.15 & 4.54 & 2.53 & 1.27 & 5.76 \\
G-5 & Flaky particle & 41.31 & 7.49 & 5.81 & 2.64 & 5.52 \\
G-5 & Flaky particle & 47.60 & 7.81 & 6.74 & 3.14 & 6.09 \\
G-5 & Flaky particle & 32.51 & 5.69 & 2.27 & 1.62 & 5.71 \\
G-6 & Pristine diatom & 31.48 & 2.58 & 15.75 & 6.24 & 12.20 \\
& & 48.10 & 4.60 & 21.92 & 5.72 & 10.46 \\
& & 49.60 & 2.73 & 7.33 & 2.79 & 18.17 \\
& & 61.78 & 4.97 & 13.33 & 5.75 & 12.43 \\
G-6 & Microsphere aggregate & 30.75 & 2.22 & - & 1.10 & 13.85 \\
& & 29.15 & 2.24 & 1.32 & 0.79 & 13.01 \\
& & 31.08 & 2.5 & 1.51 & 0.98 & 12.43 \\
G-6 & Granular particle & 26.47 & 3.23 & 1.64 & 0.94 & 8.20 \\
& & 27.75 & 3.22 & 1.61 & 1.02 & 8.62 \\
& & 28.70 & 2.64 & - & 0.74 & 10.87 \\
\hline
\end{tabular}

a Refer to Figs. 2 and 4 for sample locations and their stratigraphic positions, respectively.

\section{Pore fluid composition}

The variation in pore water-derived silicon and aluminium concentrations with respect to depth from the base of the sediment-water interface to a depth of 16 to $19 \mathrm{~cm}$ the below this surface is shown in Fig. 11. Silicon concentration just above the sediment-water interface ranges from 45 to $55 \mathrm{mg} \mathrm{L}^{-1}$. The concentration decreases with increasing depth with the greatest decrease occurring in the upper 5 to $7 \mathrm{~cm}$ of sediment, below which silicon concentration ranges from 27 to $46 \mathrm{mg} \mathrm{L}^{-1}$. Aluminium concentrations are several orders of magnitude lower than those of silicon. Above the sediment-water interface the aluminium concentration ranges from 0.005 to $0.036 \mathrm{mg} \mathrm{L}^{-1}$. In cores C, D and $\mathrm{F}$, the aluminium concentration remains relatively low fluctuating between 0.006 and $0.126 \mathrm{mg} \mathrm{L}^{-1}$, increasing slightly towards the bottom. Cores A and B, also have relatively low aluminium concentrations for much of their thickness $\left(0.007\right.$ to $0.175 \mathrm{mg} \mathrm{L}^{-1}$, apart from outliers at $0.441 \mathrm{mg} \mathrm{L}^{-1}$ in core $A$ and $0.311 \mathrm{mg} \mathrm{L}^{-1}$ in core $B$ ), however, in the lower $4 \mathrm{~cm}$ the concentration increases to $1.94 \mathrm{mg} \mathrm{L}^{-1}$ and $0.344 \mathrm{mg} \mathrm{L}^{-1}$, respectively. In core $\mathrm{E}$, the aluminium concentration is generally erratic, ranging from 0.005 to $1.87 \mathrm{mg} \mathrm{L}^{-1}$.

\section{Discussion}

\subsection{Facies origins}

The dark colour, the relative abundance of intact diatoms, high organic content and paucity of inorganic grains in facies A are consistent with undisturbed lacustrine sedimentation and early diagenesis (e.g., dark colour may be due to sulphate reduction), and similar deposits occur throughout lakes in the Rotorua region (e.g., McColl, 1977; Fish, 1979; Rawlence, 1985). The bimodal and relatively coarse grain size (c.f., facies B and C) reflects the variation in diatom size between the larger pennate and smaller centric forms. Diatom genera commonly found in Rotorua lakes include the pennate forms Asterionella, Fragilaria and Nitzchia, and the centric forms Cyclotella, Aulocoseira and Stephanodiscus (e.g., Rawlence, 1984, 1985; Reid, 2005; c.f., Lake Taupo, Jones et al., 2007) and several of these are likely to represent the dominant diatom genera in facies A. A comprehensive taxonomic characterisation of the diatom species and other flora of the lake is beyond the scope of this study. However, it is sufficient to note that the diatom assemblage in this facies is significantly different to, and more diverse than those seen in the underlying facies B. 

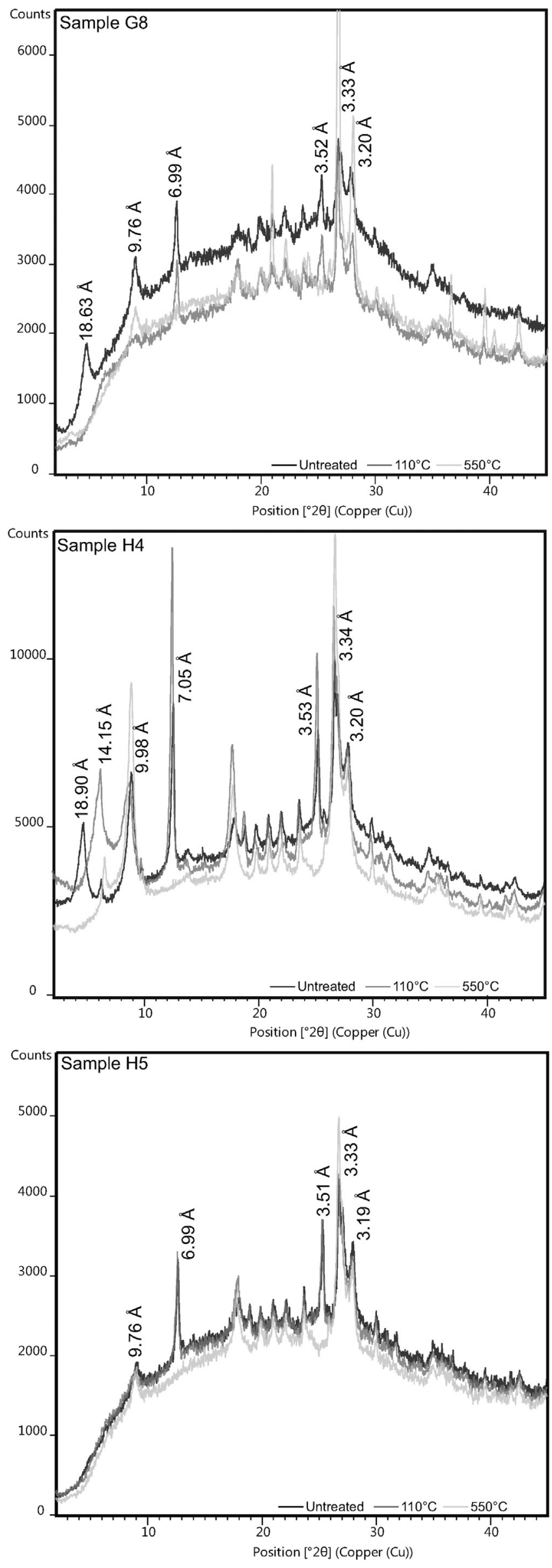

Facies $B$ is finer-grained and comprises a greater abundance of inorganic grains than facies $\mathrm{A}$, and is also comparable to the "Rotomahana Mud' marker horizon identified in other Rotorua lakes (e.g., Fish, 1979; Rawlence, 1984, 1985; Trolle et al., 2008). Subaerial deposits of the Rotomahana Pyroclastics surrounding the lake are composed of poorly sorted lithic lapilli ash (or gravel-rich deposits; Nairn, 1979; Pittari et al., in this issue) and it is likely that the primary near- and in-vent pyroclastic deposits beneath Lake Rotomahana are of similar or coarser grain size. Much of the clay to silt-sized fraction in primary subaerial deposits of the Rotomahana Pyroclastics was derived from hydrothermallyaltered country rock and weathered lake-floor sediments (Kirkman, 1976; Nairn, 1979). The clay fraction has been reported to include allophane (26-56\%), kaolin (10-18\%), illite (14-24\%), montmorillonite (20-32\%) and minor vermiculite and mordenite (N.Z. Soil Bureau, 1968; Kirkman, 1976). Coarser sand-sized grains within subaerial deposits were reported by Nairn (1979) to include crystals (abundant plagioclase and quartz, minor biotite and titomagnetite, trace hornblende and orthopyroxene), pumiceous rhyolite fragments and scoria. The upper part of facies B sampled here is significantly finer-grained (fine silt-sized) than the primary subaerial deposits, contains intact diatoms and is also laminated, which suggest that this facies is not the primary pyroclastic deposit, but rather volcaniclastic sediments re-deposited in the Rotomahana lacustrine basin. Quartz, feldspar, montmorillonoids, illite and interlayered hydrous mica, identified in facies B by XRD analyses, are likely to represent much of the flaky and granular particle population observed under SEM; their provenance is likely to be from the finegrained fraction of the Rotomahana Pyroclastics. Allophane, amorphous silica and/or glass are X-ray amorphous, but may be represented by the broad background maxima (Lowe and Nelson, 1983), particularly evident in the traces for samples G8 (facies B) and H5 (facies C) (Fig. 10).

For comparison, laminated sediments in volcanic lakes of the Long Gang Volcanic Field (N.E. China) are comprised of interlayered graded siliciclastic laminae, formed from weather events that caused high clastic input rates or generated mass flows, with diatom-rich laminae, possibly related to seasonal blooms (Mingram et al., 2004). Clay and silt sediment fractions from terrigenous sources reach the lake basin environment by sediment suspension currents fed by river plume dispersion (Phillips and Nelson, 1981). A proportion of the fragmented diatom frustules in facies B of Lake Rotomahana may have been derived from the pre-eruptive lake floor, and recycled into the modern lake as terrigenous grains, as implied in Nairn (1979). However, the black laminae, which may represent low energy periods where relatively higher concentrations organic matter could accumulate, and the preservation of intact diatom frustules, including some fragile pennate forms, implies that diatom blooms existed in the lake during the early post-eruptive period of high sediment influx into the lake.

Facies $C$ is localised around a sublacustrine vent (see also Walker et al., in this issue; de Ronde et al., in this issue) and represents hydrothermally-altered lacustrine sediment. The grain texture and composition is comparable to facies B (except XRD peaks for hydrated montmorillonoids and hydrous interlayed mica were absent in facies C), which was most likely the parent material. Surface iron-rich encrustations and discolouration of the sediment are suggestive of hydrothermal alteration. Tubular clays are morphologically comparable to tubular halloysite that could also be a product of hydrothermal alteration of either volcanic glass, feldspar, or mica crystals (Joussein et al., 2005). The occurrence of halloysite over kaolinite is inconclusive in the XRD trace for facies C (sample H5, Fig. 10), however kaolinite, if present, should have a platy morphology and thus would comprise part of the flaky or granular particle population, rather than the tubular clays.

Fig. 10. XRD traces for the clay fraction from samples G8, H4 and H5. For each sample the traces for the untreated clay fraction (black), after heating to $110{ }^{\circ} \mathrm{C}$ (medium grey) and after heating to $550{ }^{\circ} \mathrm{C}$ (light grey) are shown. The d spacings $(\AA)$ for significant peaks along the trace for the untreated samples are labelled. See Figs. 2 and 4 for sample locations and their stratigraphic positions, respectively. 

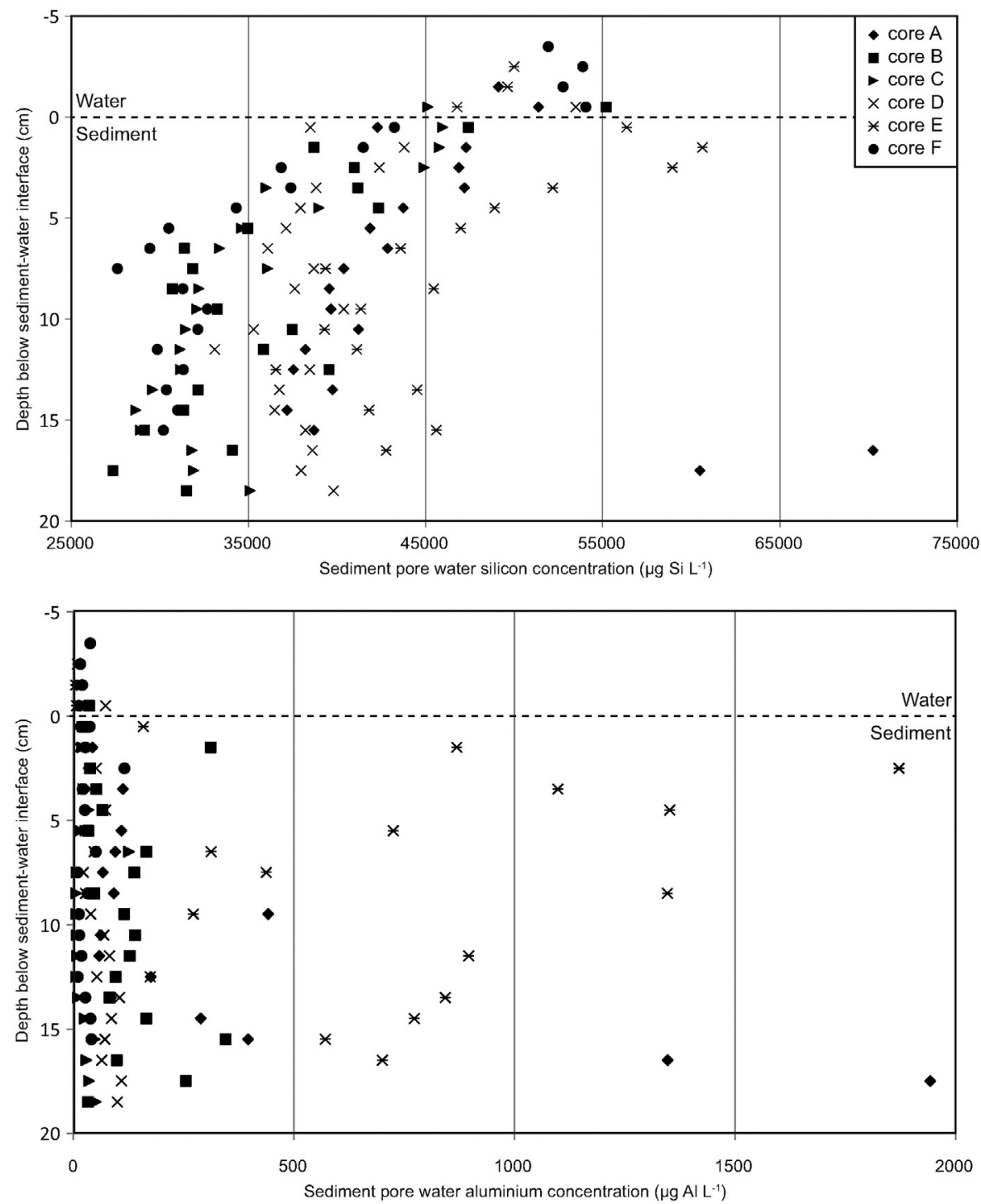

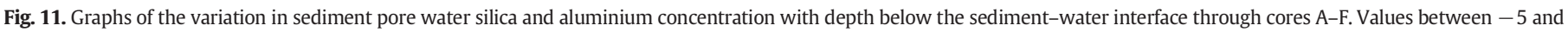
$0 \mathrm{~cm}$ are of the bottom lake water, above the sediment-water interface. See Figs. 2 and 3 for sample locations and their stratigraphic positions, respectively.

\subsection{Filling and stabilisation of the volcanic lake}

Volcanic lakes are formed or reconfigured during an eruption by crater development, or damming of catchments by volcanic debris or lavas, and may take several months to several years to fill to stable lake levels. For example, a $1.1 \mathrm{~km}$-wide summit crater that formed during a 1982 eruption of Volcán El Chichón, Mexico, began filling with water within 1 month after the eruption; within 8 months a lake $5 \times 10^{6} \mathrm{~m}^{3}$ in volume was established (Casadevall et al., 1984). Lake Taupo, New Zealand, was emptied during the $232 \mathrm{AD}$ Taupo eruption and refilled to its highest level ( $34 \mathrm{~m}$ above present lake level) over a period of only 13 to 15 years (Smith, 1991).

A comprehensive study has been undertaken on the post-eruptive re-establishment of Spirit Lake following the May 18, 1980 Mount St. Helens eruption (Larson, 1993, and references therein). Eruption debris and sediment raised the floor of Spirit Lake by $\sim 60 \mathrm{~m}$ and enclosed it by a 150-180 m-thick debris dam. Spirit Lake had been refilling for more than 2 years following the eruption, before it was artificially stabilised by a diversion tunnel. Water clarity did not reach pre-eruption levels until 6-9 years after the eruption. In the first 2 years following the eruption, the lake, except for near-surface water, fluctuated between oxygenated and anoxic conditions, and only a few diatom species were observed. Steady oxygenated conditions within the lake were achieved after 2 years and biota flourished from the third year onwards.

The stabilisation of Spirit Lake may be analogous to the establishment of the modern Lake Rotomahana in the few years following the 1886 eruption. Lake Rotomahana had filled to its present level within a decade following the eruption (Healy, 1975). Immediately following the eruption, much of the catchment area was covered by poorly-sorted gravelly sand to gravelly mud (Nairn, 1979). Significant erosional rilling of this deposit occurred within several days of the eruption (Keam, 1988) and may have continued for several years (Hardy, 2005), thus feeding substantial sediment plumes onto the lake floor. High resolution bathymetric mapping of the lake floor at Rotomahana has revealed erosional channels in the shallow area of the lake and several lacustrine fan deltas (de Ronde et al., in this issue). The final stages of this period of high sediment flux are represented by facies $B$. The occurrence of a relatively low diversity diatom assemblage in facies B may be analogous to the establishment of diatom blooms, albeit of low diversity, at Spirit Lake while it was still filling (Larson, 1993, and references therein). 


\subsection{Hydrothermal manifestations on the lake floor}

The absence of the diatomaceous pelagic sediment layer (facies A) at the top of lake-bottom cores recovered close to the sublacustrine hydrothermal vents is likely due to turbulence above the gas-rich plume, which would clear lake sediment from around the vent and inhibit sedimentation from the pelagic zone above the vent. As a consequence, the top of the re-deposited Rotomahana Pyroclastics layer (facies B) has been exposed to hydrothermal surface precipitation and sediment alteration to form facies $C$.

Sublacustrine hydrothermal surface features have been documented in several volcanic lakes (e.g., Crater Lake, Dymond et al., 1989; Collier et al., 1991; Yellowstone Lake, e.g., Morgan et al., 2003; Shanks et al., 2007; Lake Taupo, de Ronde et al., 2002; Jones et al., 2007). For example, mineralised, amorphous silica (opal-A) chimneys occur at water depths of $\sim 120$ to $135 \mathrm{~m}$ the sublacustrine Horomatangi hydrothermal field, Lake Taupo, which has been active since the ca. 232 AD Taupo eruption (de Ronde et al., 2002; Jones et al., 2007). Hydrothermal deposits may have been accumulating on the floor of Lake Rotomahana since the Tarawera eruption, as significant subaerial siliceous sinter deposits have formed in the nearby Waimangu Valley over the same period of time. However, observations of the lake floor are limited and only recent lake floor photographs of de Ronde et al. (in this issue) have identified orange-brown crusts overlying hydrothermally-altered material. Yellow-brown iron-rich surface encrustations and laminae associated with facies $\mathrm{C}$ (cores $\mathrm{E}$ and $\mathrm{H}$, this study) near a hydrothermal vent, are also comparable to the ochre to dark brown iron-rich crusts and ochre-coloured sediment layers observed on the floor of Crater Lake, Oregon (Collier et al., 1991), both of which are considered to be hydrothermal alteration features.

The occurrence of microspheres on sediment grains is of particular interest and represents chemical precipitation from pore waters. Microspheres could either be amorphous silica or spheroidal clay, potentially halloysite. Halloysite, which has an ideal formula $\mathrm{Al}_{2} \mathrm{Si}_{2} \mathrm{O}_{5}(\mathrm{OH})_{4} \cdot \mathrm{nH}_{2} \mathrm{O}$, commonly occurs in both tubular and spheroidal forms, and is typically a product of weathering or hydrothermal alteration (e.g., Adamo et al., 2001; Joussein et al., 2005). Spheroidal halloysite normally occurs as a weathering or marine alteration product of volcanic glass. Spot EDS analyses of the microspheres observed here indicate that they are composed of silicon, aluminium and some potassium and iron (Table 2). However, as noted earlier, the relative size of the small microspheres with respect to the wider EDS beam implies that there is some crosscontamination with adjacent grains. The silicon-aluminium ratio is inconsistent with the material being halloysite. The presence of halloysite in facies $\mathrm{B}$, and possible facies $\mathrm{C}$, is indicated by XRD results, but this does not necessarily imply that the halloysite occurs in the form of microspheres; it could alternatively occur as platy or tubular forms within the rest of the inorganic particle fraction. Furthermore, the microspheres do not necessarily replace, or occur as growths on, volcanic glass, but are rather ubiquitous and commonly coat the surfaces of diatom frustules. Spheroidal amorphous silica (opal-A) is common within hydrothermal sinter deposits on lake floors (e.g., de Ronde et al., 2002; Jones et al., 2007; Shanks et al., 2007) and also occurs within lake sediments in hydrothermal settings (e.g., Jones and Renaut, 2012).

The silicon concentration in the lake water above the sedimentwater interface and with the sediment pore water is very high. The vertical downward decrease in pore water silicon concentration through the upper 5-7 cm of facies C (i.e., hydrothermally altered facies B) in core $\mathrm{E}$ corresponds to the appearance of microspheres occurring at the same interval in core $\mathrm{H}$. In all other cores (A-D and F), the drop in silicon concentration occurs through the upper part of the facies A layer, whereas the appearance of microspheres in an equivalent core (core G) occurs approximately $15-25 \mathrm{~cm}$ below this transition within the underlying facies B. In contrast, aluminium concentrations are several orders of magnitude lower than silicon concentrations and tend to remain constant or increase with depth. Hence, a significantly large amount of silicon is being removed from the pore water and precipitating in the sediment, which is consistent with microspheres being siliceous precipitates from silicon-saturated pore water. Halloysite may also form from the extraction of silicon from the pore water, and could be represented by some of the microspheres. However, halloysite precipitation requires equal parts silicon and aluminium, and the vertical trends in aluminium concentration are inconsistent with the extraction of significant amounts of aluminium from the pore water.

The tubular clays observed in facies $C$ show typical morphologies of tubular halloysite, and may be a result of hydrothermal alteration of detrital grains of volcanic glass, feldspar or micas (Joussein et al., 2005). Alternatively, such grains were already hydrothermally altered fragments of the country rock that were incorporated into the Rotomahana Pyroclastics and subsequent lacustrine sediments.

\section{Conclusions}

The upper $20-46 \mathrm{~cm}$ of lake-bottom sediment beneath Lake Rotomahana comprises lacustrine silt derived from rapid, post-eruptive re-sedimentation of the Rotomahana Pyroclastics, overlain by diatomaceous pelagic silt representing physical stabilisation of the lake and reduction in terrigenous sediment influx. Near an active sublacustrine hydrothermal vent, the diatomaceous silt is absent and the upper sediments have been hydrothermally altered. Evidence for widespread silica precipitation in the sediment represents the early stages of silicification and it is possible that sinter structures are currently, or will later develop, on the lake floor. Young, hydrothermally-active volcanic lakes, elsewhere, could potentially undergo similar phases of post-eruptive development.

\section{Acknowledgements}

The support of the Te Arawa Lake Trust Board towards this study and the leadership and collaboration with C. de Ronde is greatly appreciated. GNS Science provided in-kind field support and field assistance was provided by D. Immenga, R. Briggs and H. Goddard. We would like to thank S. Walker (NOAA) for drafting Fig. 2, D. Hamilton and V. CassieCooper for advice on biological and limnological aspects of the lake, D. Lowe, J. Churchman and M. Kluger for discussion on clay mineral interpretation, W. de Lange for assistance with data processing, and $\mathrm{H}$. Turner and K. Vincent for technical support. We also thank M. Simpson and an anonymous reviewer for their constructive reviews in helping to improve the manuscript.

\section{References}

Adamo, P., Violante, P., Wilson, M.J., 2001. Tubular and spheroidal halloysite in pyroclastic deposits in the area of the Roccamonfina volcano (Southern Italy). Geoderma 99, 295-316.

Bibby, H.M., Bennie, S.L., Stagpoole, V.M., Caldwell, T.G., 1994. Resistivity structure of the Waimangu, Waikite and Reporoa geothermal areas, New Zealand. Geothermics 23 , 445-471.

Brantley, S.L., Borgia, A., Rowe, G., Fernandez, J.F., Reynolds, J.R., 1987. Poás volcano crater lake acts as a condenser for acid metal-rich brine. Nature 330, 470-472.

Caratori Tontini, F., de Ronde, C.E.J., Scott, B.J., Soengkono, S., Stagpoole, V., Timm, C., Tivey, M.A., 2015. Interpretation of gravity and magnetic anomalies at Lake Rotomahana: geological and hydrothermal implications. J. Volcanol. Geotherm. Res. (this issue).

Casadevall, T.J., de la Crus-Reyna, S., Rose Jr., W.I., Bagley, S., Finnegan, D.L., Zoller, W.H., 1984. Crater lake and post-eruptive hydrothermal activity, El Chichón Volcano, Mexico. J. Volcanol. Geotherm. Res. 23, 169-191.

Christenson, B.W., Wood, C.P., 1993. Evolution of a vent-hosted hydrothermal system beneath Ruapehu Crater Lake, New Zealand. Bull. Volcanol. 55, 547-565.

Christenson, B., Németh, K., Rouwet, D., Tassi, F., Vandemeulebrouck, J., Varekamp, J.C. 2015. Volcanic lakes. In: Rouwet, D., Christenson, B., Tassi, F., Vandemeulebrouck, J (Eds.), Volcanic Lakes. Advances in Volcanology. http://dx.doi.org/10.1007/978-3642-36833-2_1.

Cole, J.W., 1970. Structure and eruptive history of the Tarawera volcanic complex. N. Z. J. Geol. Geophys. 13, 879-902.

Collier, R.W., Dymond, J., McManus, J., 1991. Studies of hydrothermal processes in crater lake, OR. Oregan State University College of Oceanography Report 90-7 (201 pp.). 
Cunningham, M.J., 2012. Sensitive Rhyolitic Pyroclastic Deposits in the Tauranga Region: Mineralogy, Geomechanics and Microstructure of Peak and Remoulded States MSc thesis University of Waikato, Hamilton, New Zealand (309 pp.)

de Ronde, C.E.J., Stoffers, P., Garbe-Schönberg, D., Christenson, B.W., Jones, B., Manconi, R, Browne, P.R.L., Hissmann, K., Botz, R., Davy, B.W., Schmitt, M., Battershill, C.N., 2002. Discovery of active hydrothermal venting in Lake Taupo, New Zealand. J. Volcanol. Geotherm. Res. 115, 257-275.

de Ronde, C.E.J., Walker, S.L., LeBlanc, C., Davy, B.W., Fornari, D.J., Caratori, Tontini F., Scott, B.J., Seebeck, F.H., Stewart, T.J., Mazot, A., Nicol, A., Tivey, M.A., 2016. Reconstruction of the geology and structure of Lake Rotomahana and its hydrothermal systems from high-resolution multibeam mapping and seismic surveys: effects of the $1886 \mathrm{Mt}$ Tarawera eruption. J. Volcanol. Geotherm. Res. http://dx.doi.org/10.1016/j. jvolgeores.2016.02.002 (this issue)

Dymond, J., Collier, R.W., Watwood, M.E., 1989. Bacterial mats from Crater Lake, Oregon and their relationship to possible deep-lake hydrothermal venting. Nature 342 673-675.

Fish, G.R., 1979. Recent stratigraphy of sediments in Lake Rotorua. N. Z. J. Mar. Freshw. Res. 13, 529-532.

Folk, R.L., Ward, W.C., 1957. Brazos River bar: a study in the significance of grain size parameters. J. Sediment. Petrol. 27, 3-26.

Fox, B.R.S., Wartho, J., Wilson, G.S., Lee, D.E., Nelson, F.E., Kaulfuss, U., 2015. Long-term evolution of an oligocene/miocene maar lake from Otago, New Zealand. Geochem. Geophys. Geosyst. 16, 59-76.

Hardy, L., 2005. Lake Okaro: Explosions and Erosion. A study into erosion on the hills to the north of Lake Okaro and the 0.7 ka phreatic and hydrothermal eruptions a Lake Okaro to help understand the current geomorphology BSc(Hons) thesis University of Otago, Dunedin, New Zealand (66 pp.).

Healy, J., 1975. The gross effect of rainfall on lake levels in the Rotorua District. J. R. Soc. N Z. 5, 77-100.

Hunt, T.M., Glover, R.B., Wood, C.P., 1994. Waimangu, Waiotapu, and Waikite geotherma systems, New Zealand: background and history. Geothermics 23, 379-400.

Jones, B., Renaut, R.W., 2012. Facies architecture in depositional systems resulting from the interaction of acidic springs, alkaline springs, and acidic lakes: case study of Lake Roto-a-Tamaheke, Rotorua, New Zealand. Can. J. Earth Sci. 49, 1217-1250.

Jones, B., de Ronde, C.E.J., Renaut, R.W., Owen, R.B., 2007. Siliceous sublacustrine spring deposits around hydrothermal vents in Lake Taupo, New Zealand. J. Geol. Soc. Lond. 164, 227-242

Joussein, E., Petit, S., Churchman, J., Theng, B., Righi, D., Delvaux, B., 2005. Halloysite clay minerals - review. Clay Miner. 40, 383-426.

Kaulfuss, U., 2013. Geology and paleontology of Foulden Maar, Otago, New Zealand PhD Thesis University of Otago, Dunedin, New Zealand (322 pp.).

Keam, R.F., 1988. Tarawera. R.F. Keam, New Zealand (472 pp.).

Keam, R.F., 2015. The Tarawera eruption, Lake Rotomahana, and the origin of the Pink and White Terraces. J. Volcanol. Geotherm. Res. (this issue).

Kirkman, J.H., 1976. Clay mineralogy of Rotomahana sandy loam soil, North Island, New Zealand. N. Z. J. Geol. Geophys. 19, 35-41.

Kirkman, J.H., Pullar, W.A., 1978. Halloysite in late pleistocene rhyolitic tephra beds near Opotiki, coastal Bay of Plenty, North Island, New Zealand. Aust. J. Soil Res. 16, 1-8.

Larson, D., 1993. The recovery of Spirit Lake. Am. Sci. 81, 166-177.

Lowe, D.J. Nelson, C.S. 1983. Guide to the nature and methods of analysis of the clay fraction of tephras from the South Auckland region, New Zealand. Occasional Report 11. University of Waikato, Dept. Earth Sciences (69 pp.).

Marchetto, A., Ariztegui, D., Brauer, A., Lami, A., Mercuri, A.M., Sadori, L., Vigliotti, L., Wulf, S., Guilizzoni, P., 2015. Volcanic lake sediments as sensitive archives of climate and environmental change. In: Rouwet, D., Christenson, B., Tassi, F., Vandemeulebrouck, J. (Eds.), Volcanic Lakes. Advances in Volcanology. http://dx.doi.org/10.1007/978-3642-36833-2 17.

McColl, R.H.S., 1977. Chemistry of sediments in relation to trophic conditions in eight Rotorua Lakes. N. Z. J. Mar. Freshw. Res. 11, 509-523.

Mingram, J., Allen, J.R.M., Brüchmann, C., Liu, J., Luo, X., Negendank, J.F.W., Nowaczyk, N. Schettler, G., 2004. Maar- and crater lakes of the Long Gang Volcanic Field (N.E. China) - overview, laminated sediments, and vegetation history of the last 900 years. Quat. Int. 123-125, 135-147.

Morgan, L.A., Shanks III, W.C., Lovalvo, D.A., Johnson, S.Y., Stephenson, W.J., Pierce, K.L., Harlan, S.S., Finn, C.A., Lee, G., Webring, M., Schulze, B., Dühn, J., Sweeney, R., Balistrieri, L., 2003. Exploration and discovery in Yellowstone Lake: results from high-resolution sonar imaging, seismic reflection profiling, and submersibles. J. Volcanol. Geotherm. Res. 122, 221-242.
Nairn, I.A., 1979. Rotomahana-Waimangu eruption, 1886: base surge and basalt magma. N. Z. J. Geol. Geophys. 22, 363-378.

Nairn, I.A., 1989. Sheet V16AC - Mount Tarawera. Geological map of New Zealand 1:50 000. Map (1 sheet) and notes. Department of Scientific and Industrial Research, Wellington, New Zealand.

Nairn, I.A., 2002. Geology of the Okataina volcanic centre, scale 1:50 000. Institute of Geological and Nuclear Sciences Geological Map 25, 1 Sheet + 156 P. Institute of Geological and Nuclear Sciences, Lower Hutt, New Zealand.

Németh, K., Goth, K., Martin, U., Csillag, G., Suhr, P., 2008. Reconstructing paleoenvironment, eruption mechanism and paleomorphology of the Pliocene Pula maar (Hungary). J. Volcanol. Geotherm. Res. 177, 441-456.

N.Z. Soil Bureau, 1968. Soils of New Zealand. Part 3. N.Z. Soil Bur. Bull. 26, 127.

Pasternak, G.B., Varekamp, J.C., 1997. Volcanic lake systematics I. Physical constraints. Bull. Volcanol. 58, 528-538

Phillips, C.J., Nelson, C.S., 1981. Sedimentation in an artificial lake - Lake Matahina, Bay of Plenty. N. Z. J. Mar. Freshw. Res. 15, 459-473.

Pirrung, M., Fischer, C., Büchel, G., Gaupp, R., Lutz, H., Neuffer, F.-O., 2003. Lithofacies succession of maar crater deposits in the Eifel area (Germany). Terra Nova 15, 125-132.

Pittari, A., Briggs, R.M., Bowyer, D.A., 2015. Subsurface geology and ancient hydrothermal systems beneath Lake Rotomahana: evidence from lithic clasts of the $1886 \mathrm{AD}$ Rotomahana pyroclastics. J. Volcanol. Geotherm. Res. (this issue).

Rawlence, D.J., 1984. A study of pigment and diatoms in a core from Lake Rotorua, North Island, New Zealand, with emphasis on recent history. J. R. Soc. N. Z. 14, 119-132.

Rawlence, D.J., 1985. Post-Tarawera eruption (A.D. 1886) diatom stratigraphy of Lake Rotoiti, North Island, New Zealand. N. Z. J. Mar. Freshw. Res. 19, 391-397.

Reid, M., 2005. Diatom-Based Models for Reconstructing Past Water Quality and Productivity in New Zealand Lakes.

Seebeck, H., Nicol, A., Stern, T.A., Bibby, H.M., Stagpoole, V., 2010. Fault controls on the geometry and location of the Okataina Caldera, Taupo Volcanic zone, New Zealand. J. Volcanol. Geotherm. Res. 190, 136-151.

Shanks III, W.C., Alt, J.C., Morgan, L.A., 2007. Geochemistry of sublacustrine hydrothermal deposits in Yellowstone Lake - hydrothermal reactions, stable-isotope systematics, sinter deposition, and spire formation. In: Morgan, L.A. (Ed.), Integrated Geoscience Studies in the Greater Yellowstone Area - Volcanic, Tectonic, and Hydrothermal Processes in the Yellowstone Geoecosystem. U.S. Geol. Surv. Prof. Paper 1717, pp. 205-234

Simmons, S.F., O'Sullivan, M., 2010. Numerical model of the changes in geothermal activity in the Rotomahana-Waimangu system due to the 1886 eruption of Mt Tarawera. Proc. World Geothermal Congress, Bali, Indonesia, 25-29 April 2010 (6 pp.).

Simmons, S.F., Keywood, M., Scott, B.J., Keam, R.F., 1993. Irreversible change of the Rotomahana-Waimangu hydrothermal system (New Zealand) as a consequence of a volcanic eruption. Geology 21, 643-646.

Smith, R.C.M. 1991. Landscape response to a major ignimbrite eruption, Taupo Volcanic Center, New Zealand. In: Fisher, R.V., Smith, G.A. (Eds.), Sedimentation in Volcanic Settings. Soc. Econ. Paleontol. Mineral., Spec. Publ. 45, pp. 123-137.

Tivey, M.A., de Ronde, C.E.J., Caratori Tontini, F., Walker, S.L., Fornari, D.J., 2015. A novel heat flux study of a geothermally active lake - Lake Rotomahana, New Zealand. J. Volcanol. Geotherm. Res. (this issue).

Trolle, D., Hamilton, D.P., Hendy, C., Pilditch, C., 2008. Sediment and nutrient accumulation rates in sediments of twelve New Zealand lakes: influence of lake morphology, catchment characteristics and trophic state. Mar. Freshw. Res. 59, 1067-1078.

von Hochstetter, F., (translated by Sauter, E.), 1867. New Zealand: Its Physical Geography, Geology and Natural History with Special Reference to the Results of Government Expeditions in the Provinces of Auckland and Nelson. Stuttgart, J.G. Cotta., (515 pp.)

von Hochstetter, F., Petermann, A., 1864. Geological and Topographical Atlas of New Zealand. T. Delattre, Auckland.

Walker, G.P.L., Self, S., Wilson, L., 1984. Tarawera 1886, New Zealand - a basaltic plinian fissure eruption. J. Volcanol. Geotherm. Res. 21, 61-78.

Walker, S.L., de Ronde, C.E.J., Fornari, D., Tivey, M.A., Stucker, V.K., 2015. High-resolution water column survey to identify active sublacustrine hydrothermal discharge zones within Lake Rotomahana, North Island, New Zealand. J. Volcanol. Geotherm. Res. (this issue).

Whiteford, P.C., Graham, D.J., 1994. Conductive heat flow through the sediments in Lake Rotomahana, New Zealand. Geothermics 23, 527-538.

Whitton, J.S., Churchman, G.J., 1987. Standard methods for mineral analysis of soil survey samples for characterisation and classification in N.Z. Soil Bureau. N. Z. Soil Bur. Sci. Rep. 79 (27 pp.). 